\title{
Aerobic glycolysis in cancer cells supplies ATP while preventing excess metabolic thermogenesis
}

Authors: Nobuyuki Okahashi ${ }^{1}$, Tomoki Shima ${ }^{1}$, Yuya Kondo ${ }^{1}$, Chie Araki ${ }^{1}$, Shuma Tsuji ${ }^{1}$, Akane Sawai $^{1}$, Hikaru Uehara ${ }^{1}$, Susumu Kohno ${ }^{2}$, Hiroshi Shimizu ${ }^{1}$, Chiaki Takahashi ${ }^{2}$, and Fumio Matsuda ${ }^{1, *}$

\author{
Affiliations: \\ ${ }^{1}$ Department of Bioinformatic Engineering, Graduate School of Information Science and \\ Technology, Osaka University, 1-5 Yamadaoka, Suita, Osaka 565-0871, Japan \\ ${ }^{2}$ Cancer Research Institute, Kanazawa University, Kanazawa, Ishikawa 920-1192, Japan. \\ *Corresponding author.
}

Email:_fmatsuda@ist.osaka-u.ac.jp

\begin{abstract}
A general feature of cancer metabolism is ATP regeneration via substrate-level phosphorylation even under normoxic conditions (aerobic glycolysis). However, it is unclear why cancer cells prefer the inefficient aerobic glycolysis over the highly efficient process of oxidative phosphorylation for ATP regeneration. Here, we show that a beneficial aspect of aerobic glycolysis is that it reduces metabolic heat generation during ATP regeneration. ${ }^{13} \mathrm{C}$ metabolic flux analysis of 12 cultured cancer cell lines and in silico metabolic simulation revealed that metabolic heat production during ATP regeneration via aerobic glycolysis was considerably lesser than that produced via oxidative phosphorylation. The dependency on aerobic glycolysis was partly alleviated upon culturing under low temperatures. In conclusion, thermogenesis is required for maintaining thermal homeostasis and can govern aerobic glycolysis in cancer cells.
\end{abstract}

\section{Introduction:}

ATP regeneration is one of the most important processes in metabolism and is required for maintaining various cellular functions. Generally, normal human cells efficiently regenerate ATP by oxidative phosphorylation (OXPHOS) via the electron transport chain (ETC) (32 ATP/glucose, denoted as the glucose->TCA cycle pathway). By contrast, cancer cells depend on substrate-level phosphorylation for ATP regeneration even under conditions of oxygen availability (2 ATP/glucose, aerobic glycolysis) (De Berardinis and Chandel, 2016). This altered metabolic state has been ascribed to the fact that reduced ETC activity triggers metabolic rewiring toward aerobic glycolysis to meet the large ATP demand for active cell proliferation in cancer cells (Koppenol et al., 2011). However, ETC deficiency depends on the type of cancer cell lines, as certain cell types activate the ETC and more than 50\% of ATP regeneration is attributed to OXPHOS (Zu and Guppy, 2004). Moreover, cancer cells commonly catabolize 
glutamine as a carbon source to regenerate ATP via OXPHOS (glutaminolysis) (Fan et al., 2013; Yang et al., 2017). Thus, the rationale for employing aerobic glycolysis for ATP regeneration is far from understood, although several possible roles have been proposed (Liberti and Locasale, 2016).

\section{Total ATP regeneration flux is not correlated with cell proliferation rates}

In this study, we conducted ${ }^{13} \mathrm{C}$-metabolic flux analysis $\left({ }^{13} \mathrm{C}\right.$-MFA) of 12 cancer cell lines and in silico metabolic simulation. These cell lines were selected on the basis of the diversity of their expression patterns for genes associated with central carbon metabolism to obtain a global view of energy metabolism (Klijn et al., 2015) (Fig. S2). Their ability to grow in Dulbecco's modified Eagle's medium (DMEM) was also considered to reduce the bias derived from culture conditions. The specific cell proliferation rate, cell adhesion area, and the diameter of trypsinized cells were measured as visible phenotypes of cell cultures (Table S1).

Metabolic flux distributions allow quantitative comparison of flux levels among pathways (Antoniewicz, 2015; Duckwall et al., 2013) (Fig. 1A, Fig. S1, Table S1, S2, Data S1). The details of the procedure for ${ }^{13} \mathrm{C}-\mathrm{MFA}$ are provided in the Supplementary Text. It revealed that ATP was mainly regenerated by three metabolic pathways in 12 cancer cell lines: aerobic glycolysis (red arrow in Fig. 1A), glutaminolysis (blue arrow), and glucose-> TCA cycle (gray arrow). In the case of MCF-7 cells (Fig. 1A), the metabolic flux level in glycolysis, which is represented in the glyceraldehyde-3-phosphate dehydrogenase (GAPDH) reaction, was $1104 \mathrm{nmol}\left(10^{6} \mathrm{cells}^{-1} \mathrm{~h}^{-1}\right.$, whereas the flux levels of glutamate dehydrogenase (GLUDH, representing glutaminolysis flux) and the isocitrate dehydrogenase (IDH) reaction (representing glucose-> TCA cycle flux) was less than $10 \%$ of glycolytic flux (Fig. 1A). All the 12 cell lines demonstrated similar trends, that is, flux through aerobic glycolysis was generally higher than that of glutaminolysis and glucose$>$ TCA cycle (Fig. S3). However, significant variations in the flux of the GAPDH reaction among the cell lines were observed (Fig. S3). Glutaminolysis was also commonly contributed for ATP regeneration via OXPHOS, despite the large variation ranging from 24\% (HepG2) to 68\% (LC174T, Fig. 1B) (Fig. S3) (Zhang et al., 2017). Consistent with this observation, the cell lines maintained their mitochondrial membrane potential (Fig. S6). The glucose-> TCA cycle pathway was not universal because metabolic flux levels of the IDH reaction were close to zero in HepG2 and MIA PaCa-2 cells (Fig. S3). Principal component analysis revealed that there is no definite correlation between metabolic flux distributions and cell origins (Fig.1B), suggesting that the variations may be due to other biological contexts of each cell line.

Net ATP regeneration rates within the central carbon metabolic network were calculated from the metabolic flux distributions (Fig. 1C). For instance, the net ATP regeneration rate in MCF-7 cells was $1815 \mathrm{nmol}\left(10^{6} \text { cells }\right)^{-1} \mathrm{~h}^{-1}$, in which $39 \%$ of the ATP was regenerated by OXPHOS via the ETC (Fig. 1C). The net ATP regeneration rates varied 2.8 times among the 12 cell lines and were larger than that in most non-cancerous cells (See Supplementary Text 2 for details). Given that cell maintain a rapid turnover of ATP, it can be assumed that an equal amount of regenerated ATP must be consumed for some cellular function, such as proliferation. However, there was no correlation between the ATP regeneration rates and specific cell proliferation rates $(r=0.06$, Fig. 1D, Fig. S4), suggesting that there are other major ATP demands in cultured cancer cells. From the correlation analysis, we found that the cell adhesion area on the culture plates exhibited a positive correlation with net ATP regeneration rates $(r=0.76$, Fig. 1D and S4). This trend was also observed when an outlier (Caki-1) was removed from the dataset $(r=0.68$, Fig. S5). 
Moreover, there was no correlation between the cell adhesion area and the diameter of trypsinized floating cells ( $r=0.07$, Fig. 1D). Thus, the cell adhesion area is a phenotype of cancer cells distinct from the cell volume. It has been reported that adhesion between the cell and the extracellular matrix mediated by cadherins promotes cancer cell invasion, in conjunction with metabolic changes to produce the required amount of ATP (Sousa et al., 2019). Actin and myosin utilize ATP to play key roles in regulating tumor cell adhesion and migration (Ouderkirk and Krendel, 2014; Zanotelli et al., 2018). Taken together, cancer cell metabolism was not shaped by a proliferation-oriented mechanism.
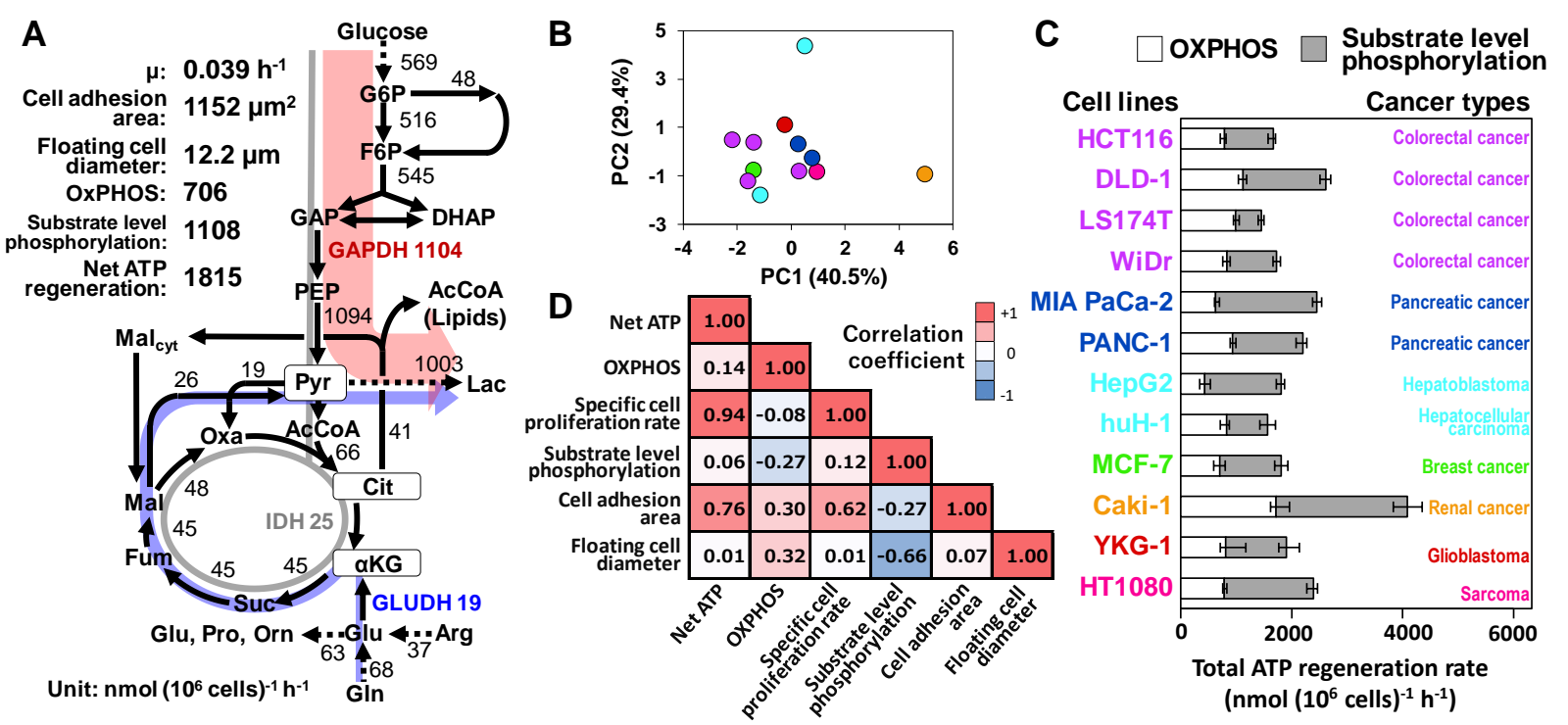

Figure 1 Variation in metabolic flux distribution among 12 cancer cell lines and their correlation with the phenotypes. (A) Metabolic flux distribution of $\mathrm{MCF}-7$ as determined by ${ }^{13} \mathrm{C}$ MFA. (B) The score plot of the principal component analysis using metabolic flux distributions of 12 cell lines. The color legend is identical to that of the next panel. (C) Variations in ATP regeneration rates by substrate-level phosphorylation and OXPHOS. Error bars represent 95\% confidence intervals. (D) Correlation of ATP regeneration rates and visible cell phenotypes. Spearman's rank order correlation coefficients are depicted in the heat map $(n=12)$.

\section{ATP demand is maintained via the coordination of glycolysis and ETC activity}

Next, we focused on the different contribution of aerobic glycolysis and OXPHOS for net ATP regeneration (Fig. 1C). The variation is likely to be derived from their distinct ETC activities depending on variable biological contexts of each cell line. It is reasonable to assume that the ETC has to work within an optimal capacity, as a loss of mitochondrial membrane potential by low ETC activity triggers cell apoptosis (Li et al., 2003; Ly et al., 2003) and an ETC overload causes excess generation of reaction oxygen species, which also induces cell apoptosis (Zhao et al., 2019). To investigate the relevance of ETC capacity and central carbon metabolism, the MCF-7 cells were treated with various ETC inhibitors. The dose-response experiment revealed that a high dose of rotenone (complex I inhibitor, $10 \mu \mathrm{M}$ ) induced rapid cell death, indicating that a severe inhibition of ETC, below the lower limit, induced apoptosis (Zielinski et al., 2017). Rotenone treatment at $100 \mathrm{nM}$ partially inhibited cell proliferation by $25 \%$ at $24 \mathrm{~h}$ (data not 
shown). The time-course data showed that cell proliferation was temporary halted by $6 \mathrm{~h}$ and then recovered between 6 and $24 \mathrm{~h}$ (Fig. 2A). The recovery in growth was accompanied by an activation of aerobic glycolysis, as the specific rates for glucose consumption and lactate production between 12 and $24 \mathrm{~h}$ were elevated by 1.2 fold upon rotenone treatment (Fig. 2B). Tracer analysis using $\left[\mathrm{U}-{ }^{13} \mathrm{C}\right]$ glutamine revealed that the relative abundance of the $\mathrm{m}+4$ isotopomer of citrate, which is produced from acetyl-CoA and oxaloacetate, was reduced upon rotenone treatment (Fig. 2C). Moreover, metabolome analysis showed that rotenone treatment induced an accumulation of malate and lactate as well as a decrease in citrate and isocitrate levels. A similar metabolic profile was commonly induced by other ETC inhibitors, metformin, antimycin, and oligomycin, but not by the mitochondrial uncoupler FCCP (Fig. 2D). These results suggested that an ETC overload caused by ETC inhibitors was circumvented by a downregulation of the entry point of the TCA cycle and the activation of aerobic glycolysis (Fig. 2E).
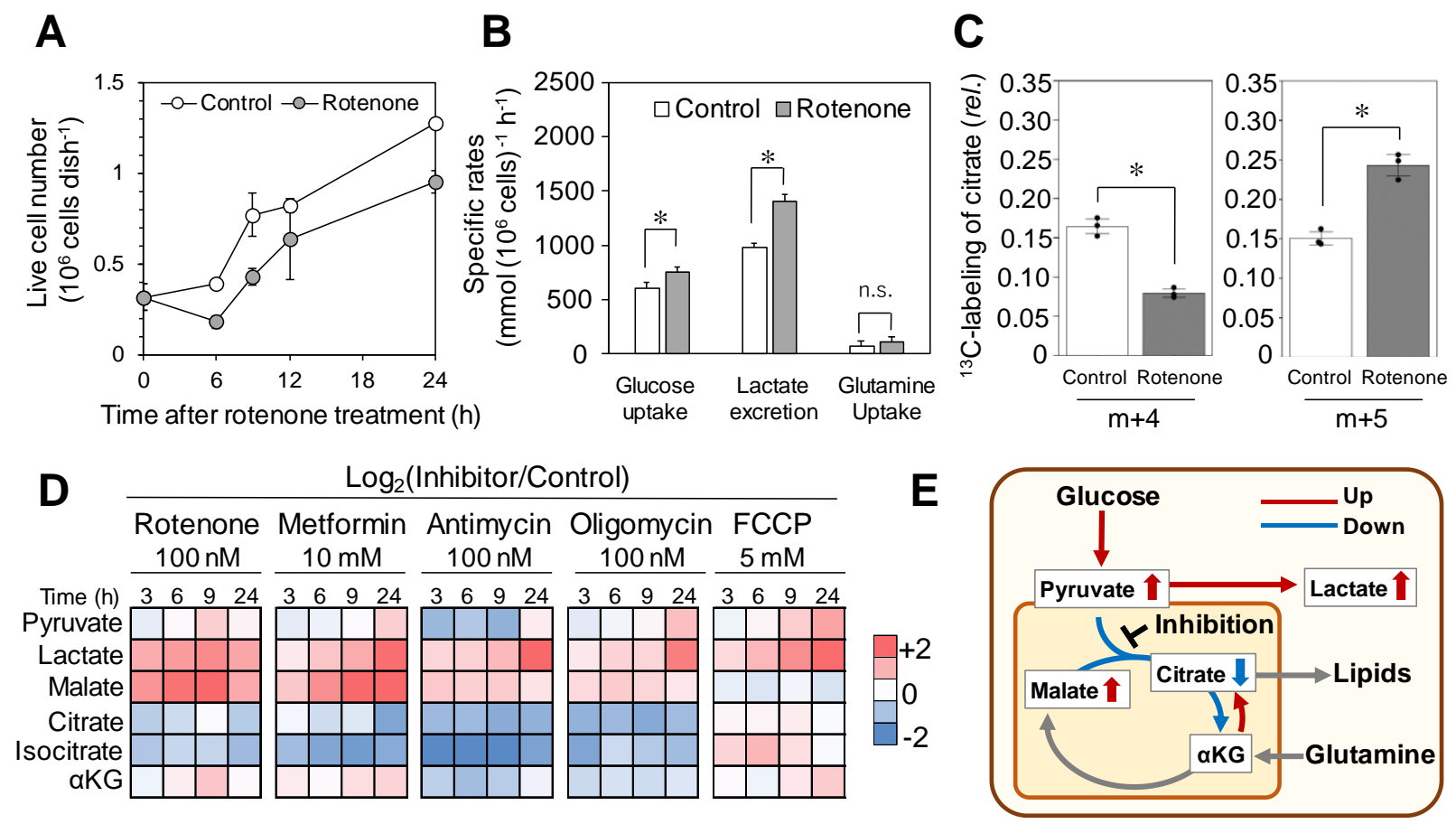

Figure 2. ETC overload caused by ETC inhibitor treatment induces metabolic rewiring

130 toward aerobic glycolysis. (A) Proliferation of MCF-7 cells upon rotenone treatment. (B) Specific rates for glucose and glutamine uptake and lactate excretion between 12 and $24 \mathrm{~h}$ of culture. Asterisks indicate statistical significance relative to the control, as determined by a twosided Student's $t$-test $(p<0.05)$. (C) Mass isotopomer distribution of citrate in MCF-7 cells in $\left[\mathrm{U}-{ }^{13} \mathrm{C}\right]$ glutamine tracing. (D) Metabolites of MCF-7 cells treated with OXPHOS inhibitors.

135 Relative abundances of metabolites $\left(\log _{2}\right.$ (fold change)) are shown in the heatmap. (E) Metabolic rewiring induced by ETC inhibitors. All data are mean $\pm \operatorname{SD}(n=3)$.

\section{In silico simulation indicates that aerobic glycolysis is required to reduce metabolic heat}

To estimate the principle behind the coordination of cancer metabolism, we explored the 140 metabolic constraints required to reproduce the measured flux distributions using in silico metabolic simulations. Flux balance analysis (FBA) using a genome-scale model of human metabolism (RECON2) was performed (Feist and Palsson, 2010) (Data S2). FBA needs an 
objective function to simulate an intracellular metabolic flux distribution by a linear programming method (Feist and Palsson, 2010). Although maximal biomass production has been commonly used as an objective function to simulate bacterial metabolism, a suitable objective function for the simulation of cancer cell metabolism remains under investigation (Zielinski et al., 2017). In this study, the ${ }^{13} \mathrm{C}-\mathrm{MFA}$ results suggested that the cultured cancer cells consumed a large amount of ATP to maintain certain cellular functions, other than for proliferation (Fig. 1D). Thus, maximal ATP consumption was employed as the objective function in the following in $150 \quad$ silico analysis.

FBA also requires constraints of the solution space (upper and lower boundaries of metabolic flux vector) (Orth et al., 2010). For instance, several FBA studies have constrained uptake rates of carbon sources, such as glucose and glutamine, and predict an intracellular metabolic flux distribution. Here, we performed FBA to determine additional constraints that compel cell metabolism to be directed toward aerobic glycolysis and glutaminolysis for ATP regeneration with limited activity of ETC, as has been revealed in the ${ }^{13} \mathrm{C}-\mathrm{MFA}$ (Fig. 1). The flux distribution of MCF-7 was chosen as an example to be reproduced by FBA (Fig. 3A). The relatively minor metabolic fluxes such as biomass synthesis as well as the uptake and production of amino acids other than glutamine were constrained at measured values of MCF-7 (all constraints for the influx and efflux are shown in Table S3). By contrast, no specific constraints were settled on the uptake rates of glucose, glutamine, and oxygen, and the excretion rates of lactate, carbon dioxide, and water.

The FBA results showed that considerable amounts of glucose and glutamine were consumed until the ATP regeneration rate reached an upper limit (Fig. 3B, Data S3). The predicted metabolic flux distribution exhibited mainly OXPHOS-dependent metabolism via glucose->TCA cycle, and a low correlation coefficient with that observed in MCF-7 cells $(r=0.62)$, suggesting that additional constraints are needed to reproduce the measured value for MCF-7. Here, we considered various thermodynamic parameters that govern cell metabolism (Niebel et al., 2019). For example, the whole stoichiometry of aerobic glycolysis (glucose $=2$ lactate) indicates that metabolic heat generation $\left(-\Delta_{\mathrm{r}} H^{\circ}\right)$ per regeneration of 1 mole of ATP by aerobic glycolysis is 53 $\mathrm{kJ}$ (mol ATP) ${ }^{-1}$ (Table S4) (Alberty, 1998). Similarly, the heat generation level by the glucose$>$ TCA cycle reaction was $88.2 \mathrm{~kJ}(\text { mol ATP })^{-1}$ (Table S4). Thus, it is expected that if there is a limitation in thermogenesis, aerobic glycolysis would be preferentially employed in cells for ATP regeneration. In fact, thermogenesis has long been observed in patients with breast cancer (Cavaliere et al., 1967). The preference for aerobic glycolysis was not observed for other parameters such as entropy and Gibbs free energy (Table S4). Thus, the genome-scale metabolic model was modified to determine levels of cellular dissipation of metabolic heat $\left(-\Delta_{\mathrm{r}} H^{\circ}\right)^{\circ}$ from the FBA results (Data S2 and Table S5) (Alberty, 1998). FBA was performed by fixing the $\Delta_{\mathrm{r}} H^{\circ}$ level at an arbitrary value as an additional constraint. We found that when $-\Delta_{\mathrm{r}} H^{\circ}$ level 180 was fixed at $84.50 \mathrm{~mJ}\left(10^{6} \text { cells }\right)^{-1} \mathrm{~h}^{-1}$, the net ATP regeneration rate in the simulated metabolic flux distribution was close to the measured value (Fig. 3C, Data S3). The predicted metabolic flux distribution (Fig. 3C, Data S3) was more similar to the measured MCF-7 data (Fig. 3A, $r=$ 0.92) because aerobic glycolysis was reproduced for ATP regeneration as expected above.

In addition to metabolic heat, ETC capacity was applied as an additional constraint because the level of ETC flux in the above simulation was zero (Fig. 3C), which is inconsistent with the measured data (Fig. S6). FBA was performed by fixing the metabolic flux level of complex IV of ETC at the measured value of MCF-7 $\left(282 \mathrm{nmol}\left(10^{6} \text { cells }\right)^{-1} \mathrm{~h}^{-1}\right)$. The predicted metabolic flux distribution successfully reproduced ATP regeneration by both aerobic glycolysis and 
glutaminolysis, whose correlation with the measured flux distributions was $r=0.98$ (Fig. 3D, Data S3). These results indicated that metabolic heat dissipation per 1 mole of ATP regenerated by glutaminolysis is smaller than that of the glucose-> TCA cycle reaction, although the detailed $-\Delta_{\mathrm{r}} H^{\circ}$ level cannot be calculated by the simple materials balance. Similar results were obtained by FBA for all 12 cell lines (Data S3 and Fig S7). These results suggested that the ETC activity and metabolic heat generation shape cancer cell metabolism.

A

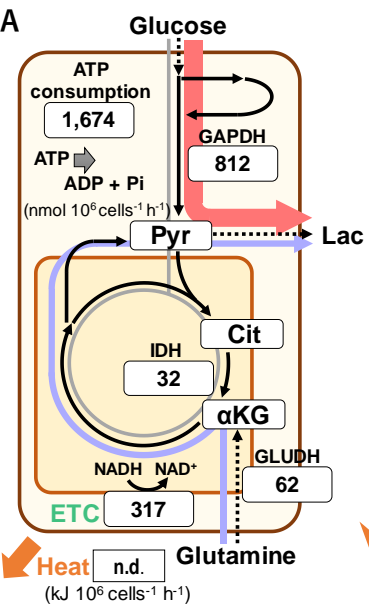

Measured (HCT116)

Objective function

Metabolic heat dissipation

ETC level (complex IV)

Correlation to HCT116 data
B

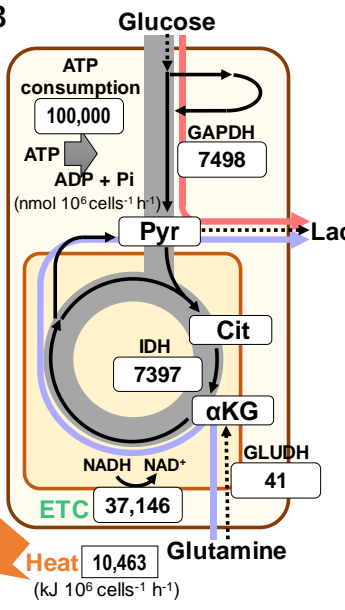

Simulated case 1
C

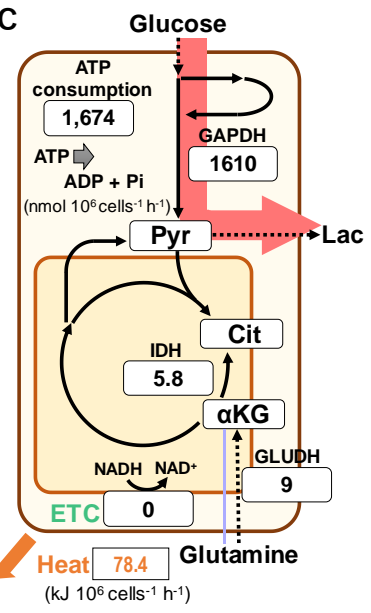

Simulated case 2

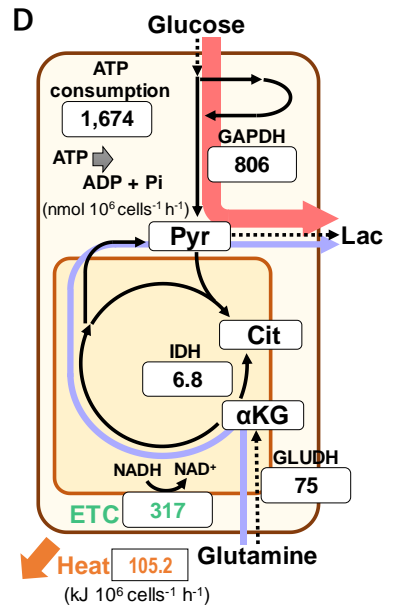

Simulated case 3 ATP consumption max Predicted Predicted $r=0.61$

ATP consumption max

Fixed at 105.2

Fixed at 317 $r=0.94$

\section{Figure 3 Metabolic heat dissipation and ETC activity govern cancer cell metabolism.}

In silico simulation of metabolism was performed by FBA using a genome-scale model of human metabolism (RECON2). Metabolic flux levels of the key reactions of aerobic glycolysis (red), glucose-> TCA cycle (gray), and glutaminolysis (blue) are depicted in the boxes. Maximum ATP consumption was employed as an objective function. Additional constraints are represented by yellow and green-colored numbers. (A) Measured metabolic flux distribution of MCF-7 cells. (B-D) Results of FBA (B) without additional constraints, (C) with a fixed metabolic heat dissipation, and (D) with fixed metabolic flux dissipation and ETC flux.

\section{Metabolic rewiring toward aerobic glycolysis is dependent on temperature}

To test the relevance of metabolism and heat dissipation, cell lines were cultured under control $\left(37^{\circ} \mathrm{C}\right)$, low $\left(36^{\circ} \mathrm{C}\right)$, and high $\left(38^{\circ} \mathrm{C}\right)$ temperatures. A comparison of the glucose and lactate concentrations in the culture medium at $18 \mathrm{~h}$ showed that lactate production tended to decrease at $36^{\circ} \mathrm{C}$ and increase at $38^{\circ} \mathrm{C}$ (Fig. 4B), whereas there was a limited effect on the glucose

210 concentration (Fig. 4A). A significant increase in lactate production was observed for two cell lines at $38^{\circ} \mathrm{C}$ ( $t$-test, $n=3$, alpha $\left.=0.05\right)$. In contrast, a significant decrease was observed for five cell lines at $36^{\circ} \mathrm{C}$. The results indicated that the metabolic shift toward the glucose-> TCA cycle pathway was temperature sensitive.

Gene expression data were obtained from MCF-7 and HCT116 cells cultured under identical 215 conditions as representative cell lines ( $n=1$, Table S6 and Data S4). A total of 3154 and 4533 open reading frames whose expression levels were altered in MCF-7 and HCT116 cells in a 
$\left[36^{\circ} \mathrm{C}\right]>\left[37^{\circ} \mathrm{C}\right]>\left[38^{\circ} \mathrm{C}\right]$ order were selected. A total of 683 ORFs were common in the MCF-7 and HCT116 datasets (Fig. 3C, Data S4, S5), which was significantly larger than the expected number of overlapped ORFs $\left(545\right.$ ORFs, $\chi^{2}$ test, $p$-value $\left.=2.0 \times 10^{-9}\right)$. An over-represented analysis was performed for the 683 ORFs using the KEGG 2019 human dataset (Xie et al., 2021). The result revealed that ORFs in the "TCA cycle" category (PDHA1, MDH2, IDH3G,

$I D H 2, I D H 3 B, O G D H L, D L A T$, and $S D H D$ ) were enriched in the 683 ORFs (Fig. 3D, Table S7). It should be noted that PDHAI and DLAT encode subunits of the pyruvate dehydrogenase complex, which is located at the entry point of the TCA cycle and was also indicated in the above-mentioned metabolome analysis (Fig. 2E). No functional category was found in the ORF list that exhibited a reversed expression pattern, in the order $\left[36^{\circ} \mathrm{C}\right]<\left[37^{\circ} \mathrm{C}\right]<\left[38^{\circ} \mathrm{C}\right]$ (data not shown). These results suggested that the metabolic rewiring from glucose->TCA cycle to aerobic glycolysis is associated with heat homeostasis.
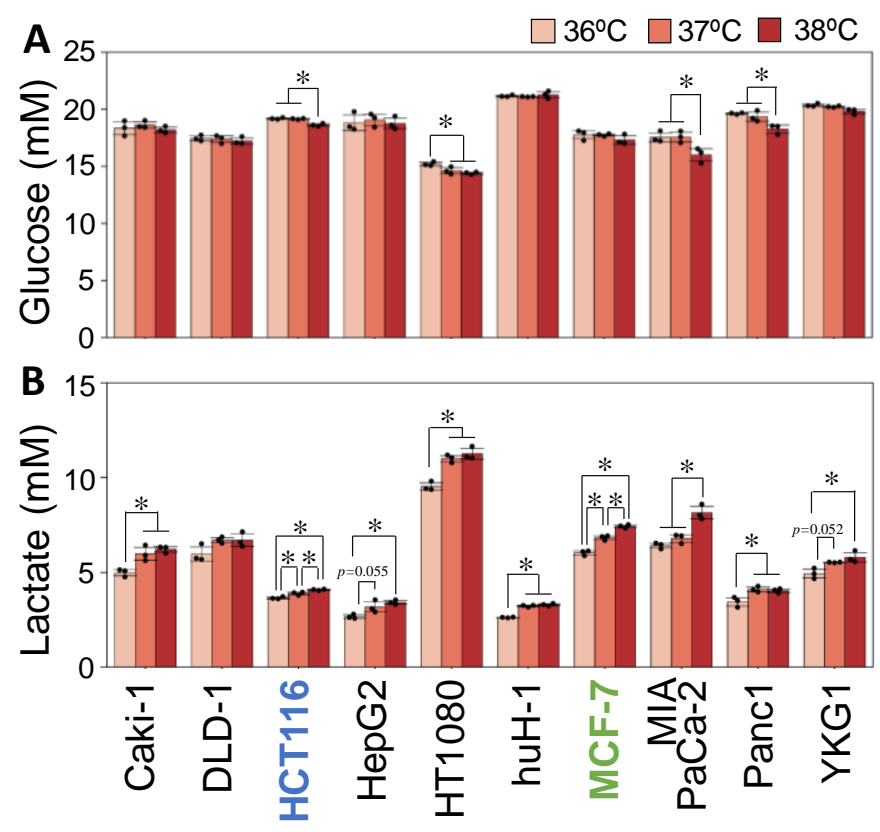

C mRNA level $\left[36^{\circ} \mathrm{C}\right]>\left[37^{\circ} \mathrm{C}\right]>\left[38^{\circ} \mathrm{C}\right]$ Total 26,256 ORFs

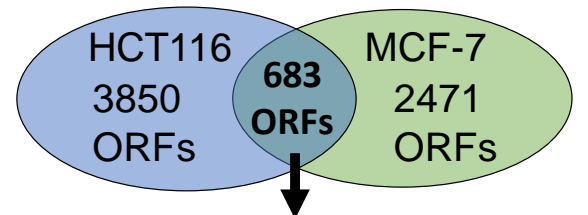

Enrichment analysis (KEGG 2019 Human)

D

Term Adjusted $p$-value

Cell cycle $1.43 \mathrm{E}-05$

Proteasome $1.43 \mathrm{E}-05$

Spliceosome

2.10E-05

$8.40 \mathrm{E}-05$

DNA replication

Citrate cycle (TCA cycle)

Oocyte meiosis

Mismatch repair

Pyruvate metabolism
$1.54 \mathrm{E}-04$

0.00722

0.0234

0.0414

Figure 4. Culture temperature induces metabolic rewiring by altering gene expression. Cancer cells were cultured under control $\left(37^{\circ} \mathrm{C}\right)$, low $\left(36^{\circ} \mathrm{C}\right)$, and high $\left(38^{\circ} \mathrm{C}\right)$ temperature conditions. Concentration of (A) glucose and (B) lactate in the culture medium at $18 \mathrm{~h}$. Data are mean $\pm \mathrm{SD}(n=3)$. Asterisks indicate statistical significance of concentrations under test conditions as determined by one way ANOVA with Tukey-Kramer method $(* p<0.05)$. (C) Venn diagram of temperature-responsive genes. RNA-Seq of MCF-7 and HCT116 cells at $18 \mathrm{~h}$ identified 3154 and 4533 genes expressed with fold changes in the $\left[36^{\circ} \mathrm{C}\right]>\left[37^{\circ} \mathrm{C}\right]>\left[38^{\circ} \mathrm{C}\right]$ order. (D) An over-represented analysis of gene categories of 683 common genes by Enricher using the KEGG 2019 Human dataset (Xie et al., 2021).

\section{Discussion}

This study reaffirms the fact that thermogenesis is an important aspect of cellular metabolism, particularly when cancer cells require large amounts of ATP. In fact, metabolic simulation 
indicated that the amount of heat generated in MCF-7 cells was estimated to be $108 \mathrm{~mJ}\left(10^{6}\right.$ cells $)^{-1} \mathrm{~h}^{-1}$ (Fig. 3D), which is much higher than that required to increase the temperature of cultured cells by $1{ }^{\circ} \mathrm{C}\left[7.4 \mathrm{~mJ}\left(10^{6} \text { cells }\right)^{-1}\right]$, assuming that the cells are filled with $1.76 \mathrm{pl}$ of water. A scenario of the effects of thermogenesis on cancer cell metabolism is summarized in Figure 5. When cancer cells require large amounts of ATP, it is desirable that they make active use of the OXPHOS pathway, which produces large amount of metabolic heat but regenerates ATP efficiently (Fig 5A). Although OXPHOS indeed contributes to ATP regeneration, no cellular metabolism dependent solely on OXPHOS was observed; all was in combination with aerobic glycolysis (Fig. 1C). The reason may be explained by the hypothesis that in order to maintain the physiological state, cellular thermogenesis in glucose->TCA cycle must be limited and the lack of ATP is compensated by aerobic glycolysis (Fig. 5B). The relevance between heat and metabolism was suggested by in silico simulation (Fig. 3) and validated by culture experiments under low and high temperatures (Fig. 4). Inhibition of ETC activity induced the metabolic rewiring for increased aerobic glycolysis (Fig. 2). Thus, cell metabolism operates within appropriate ranges of metabolic heat generation and ETC activity. This means that external heat radiation regulates respiration, as demonstrated in hyperthermia (Cavaliere et al., 1967).These results provide new insights into the relevance of cancer metabolism and cancer malignancy, cancer microenvironment interactions, and drug resistance (Liberti and Locasale, 2016). Heat generation may also be involved in the activation of immune cells and the control of the cancer microenvironment (Kokolus et al., 2013; Repasky et al., 2013). Furthermore, the relationship between metabolism and heat could be universal. It has been reported that aerobic glycolysis is observed in normal cells such as astrocytes, embryos, and stem cells (Abe et al., 2006; Ito and Suda, 2014; Miyazawa et al., 2017). Indeed, these tissues and cells commonly demand large amounts of ATP for biochemical processes, but an embryo without blood vessels has a limited capacity to release heat. The role of aerobic glycolysis in cancer and healthy cells should be analyzed while keeping heat homeostasis under consideration. 


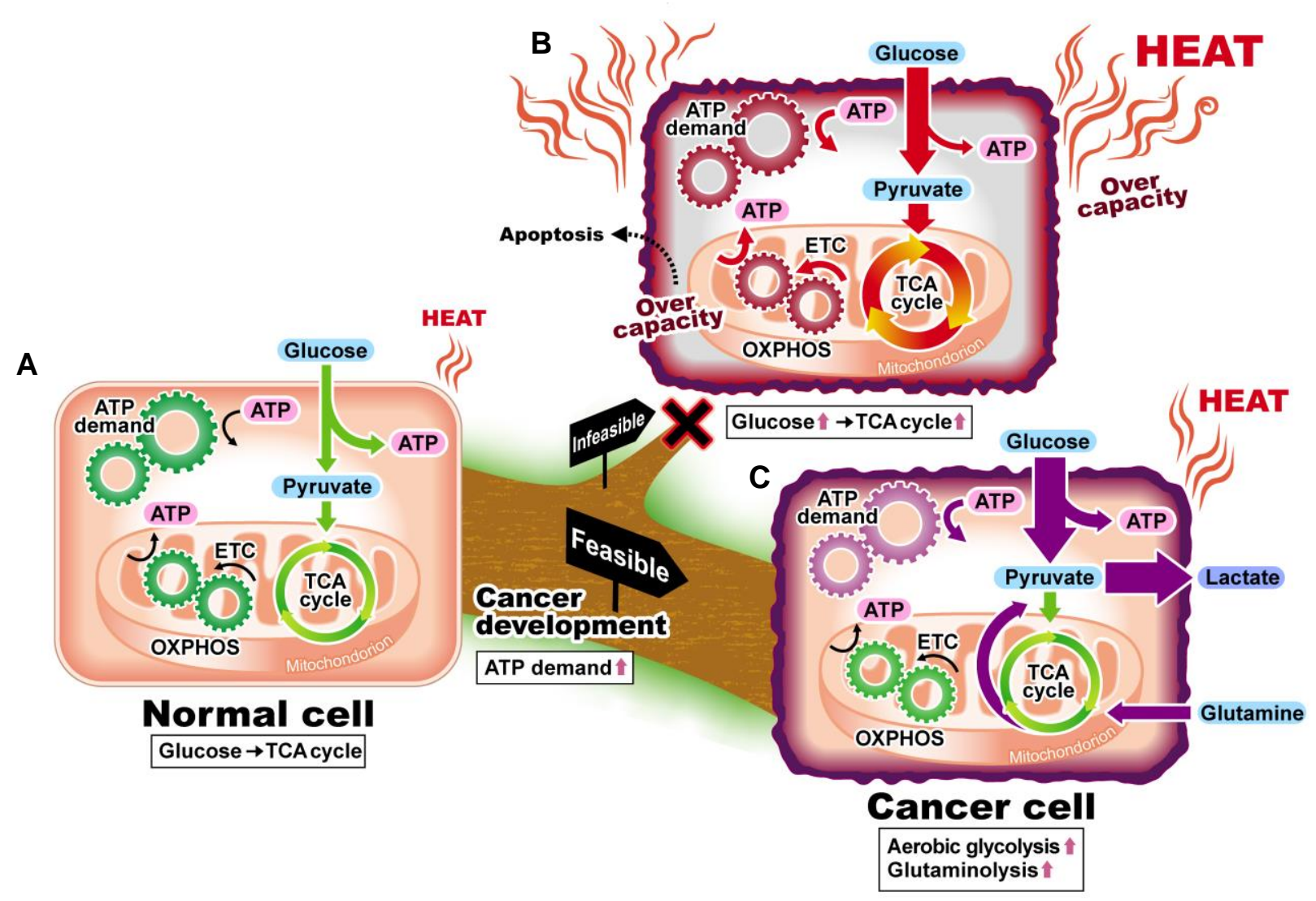

Figure 5. Cancer cell metabolism provides a large supply of ATP with less heat generation. (A) Normal cells can be assumed to regenerate ATP via the glucose->TCA cycle pathway and maintain metabolic heat dissipation and ETC activity within adequate levels. (B) Cancer cells have a high demand for ATP, but additional activation of the glucose->TCA cycle pathway is limited, as otherwise ETC activity and metabolic heat dissipation would exceed the permissible range. (C) To avoid this scenario, cancer cells rewire their metabolism to favor aerobic glycolysis, and glutaminolysis to increase their ATP supply and to fulfill ETC activities, respectively, with less metabolic thermogenesis.

\section{References}

1. R. J. De Berardinis, N. S. Chandel, Fundamentals of cancer metabolism. Sci. Adv. 2 (2016).

2. W. H. Koppenol, P. L. Bounds, C. V. Dang, Otto Warburg's contributions to current concepts of cancer metabolism. Nat. Rev. Cancer. 11, 325-337 (2011).

3. X. L. Zu, M. Guppy, Cancer metabolism: Facts, fantasy, and fiction. Biochem. Biophys. Res. Commun. 313, 459-465 (2004).

4. J. Fan, J. J. Kamphorst, R. Mathew, M. K. Chung, E. White, T. Shlomi, J. D. Rabinowitz, Glutamine-driven oxidative phosphorylation is a major ATP source in transformed mammalian cells in both normoxia and hypoxia. Mol. Syst. Biol. 9, 712 (2013). 
5. L. Yang, S. Venneti, D. Nagrath, Glutaminolysis: A Hallmark of Cancer Metabolism. Annu. Rev. Biomed. Eng. 19, 163-194 (2017).

6. M. V. Liberti, J. W. Locasale, The Warburg Effect: How Does it Benefit Cancer Cells? Trends Biochem. Sci. 41, 211-218 (2016).

7. C. Klijn, S. Durinck, E. W. Stawiski, P. M. Haverty, Z. Jiang, H. Liu, J. Degenhardt, O. Mayba, F. Gnad, J. Liu, G. Pau, J. Reeder, Y. Cao, K. Mukhyala, S. K. Selvaraj, M. Yu, G. J. Zynda, M. J. Brauer, T. D. Wu, R. C. Gentleman, G. Manning, R. L. Yauch, R. Bourgon, D. Stokoe, Z. Modrusan, R. M. Neve, F. J. de Sauvage, J. Settleman, S. Seshagiri, Z. Zhang, A comprehensive transcriptional portrait of human cancer cell lines. Nat. Biotechnol. 33, 306-312 (2015).

8. C. S. Duckwall, T. A. Murphy, J. D. Young, Mapping cancer cell metabolism with(13)C flux analysis: Recent progress and future challenges. J. Carcinog. 12, 13 (2013).

9. M. R. Antoniewicz, Methods and advances in metabolic flux analysis: a mini-review. $J$. Ind. Microbiol. Biotechnol. 42, 317-325 (2015).

10. J. Zhang, N. N. Pavlova, C. B. Thompson, Cancer cell metabolism: the essential role of the nonessential amino acid, glutamine. EMBO J. 36, 1302-1315 (2017).

11. B. Sousa, J. Pereira, J. Paredes, The crosstalk between cell adhesion and cancer metabolism. Int. J. Mol. Sci. 20, 1933 (2019).

12. J. L. Ouderkirk, M. Krendel, Non-muscle myosins in tumor progression, cancer cell invasion, and metastasis. Cytoskeleton. 71, 447-463 (2014).

13. M. R. Zanotelli, Z. E. Goldblatt, J. P. Miller, F. Bordeleau, J. Li, J. A. VanderBurgh, M. C. Lampi, M. R. King, C. A. Reinhart-King, Regulation of ATP utilization during metastatic cell migration by collagen architecture. Mol. Biol. Cell. 29, 1-9 (2018).

14. J. D. Ly, D. R. Grubb, A. Lawen, The mitochondrial membrane potential $(\delta \psi m)$ in apoptosis; an update. Apoptosis. 8, 115-128 (2003).

15. N. Li, K. Ragheb, G. Lawler, J. Sturgis, B. Rajwa, J. A. Melendez, J. P. Robinson, Mitochondrial complex I inhibitor rotenone induces apoptosis through enhancing mitochondrial reactive oxygen species production. J. Biol. Chem. 278, 8516-8525 (2003).

16. R. Z. Zhao, S. Jiang, L. Zhang, Z. Bin Yu, Mitochondrial electron transport chain, ROS generation and uncoupling (Review). Int. J. Mol. Med. 44, 3-15 (2019).

17. D. C. Zielinski, N. Jamshidi, A. J. Corbett, A. Bordbar, A. Thomas, B. O. Palsson, Systems biology analysis of drivers underlying hallmarks of cancer cell metabolism. Sci. Rep. 7, 1-14 (2017).

18. A. M. Feist, B. O. Palsson, The biomass objective function. Curr. Opin. Microbiol. 13, 344-349 (2010).

19. J. D. Orth, I. Thiele, B. Ø. Palsson, What is flux balance analysis? Nat. Biotechnol. 28, 245-248 (2010).

20. B. Niebel, S. Leupold, M. Heinemann, An upper limit on Gibbs energy dissipation governs cellular metabolism. Nat. Metab. 1, 125-132 (2019). 
22. R. Cavaliere, E. C. Ciocatto, B. C. Giovanella, C. Heidelberger, R. O. Johnson, M. Margottini, B. Mondovi, G. Moricca, A. Rossi-Fanelli, Selective heat sensitivity of cancer cells. Biochemical and clinical studies. Cancer. 20, 1351-1381 (1967).

23. Z. Xie, A. Bailey, M. V Kuleshov, D. J. B. Clarke, J. E. Evangelista, S. L. Jenkins, A. Lachmann, M. L. Wojciechowicz, E. Kropiwnicki, K. M. Jagodnik, M. Jeon, A. Ma'ayan, Gene Set Knowledge Discovery with Enrichr. Curr. Protoc. 1, e90 (2021).

24. K. M. Kokolus, M. L. Capitano, C. T. Lee, J. W. L. Eng, J. D. Waight, B. L. Hylander, S. Sexton, C. C. Hong, C. J. Gordon, S. I. Abrams, E. A. Repasky, Baseline tumor growth and immune control in laboratory mice are significantly influenced by subthermoneutral housing temperature. Proc. Natl. Acad. Sci. U. S. A. 110, 20176-20181 (2013).

25. E. A. Repasky, S. S. Evans, M. W. Dewhirst, Temperature matters! And why it should matter to tumor immunologists. Cancer Immunol. Res. 1, 210-216, (2013).

26. T. Abe, S. Takahashi, N. Suzuki, Oxidative metabolism in cultured rat astroglia: Effects 345 of reducing the glucose concentration in the culture medium and of D-aspartate or potassium stimulation. J. Cereb. Blood Flow Metab. 26, 153-160 (2006).

27. H. Miyazawa, Y. Yamaguchi, Y. Sugiura, K. Honda, K. Kondo, F. Matsuda, T. Yamamoto, M. Suematsu, M. Miura, Rewiring of embryonic glucose metabolism via suppression of PFK-1 and aldolase during mouse chorioallantoic branching. Development. 144, 63-73 (2017).

28. K. Ito, T. Suda, Metabolic requirements for the maintenance of self-renewing stem cells. Nat. Rev. Mol. Cell Biol. 15, 243-256 (2014).

29. N. Okahashi, S. Kohno, S. Kitajima, F. Matsuda, C. Takahashi, H. Shimizu, Metabolic characterization of cultured mammalian cells by mass balance analysis, tracer labeling 355 experiments and computer-aided simulations. J. Biosci. Bioeng. 120, 725-731 (2015). 30. C. Araki, N. Okahashi, K. Maeda, H. Shimizu, F. Matsuda, Mass spectrometry-based method to study inhibitor-induced metabolic redirection in the central metabolism of cancer cells. Mass Spectrom. 7, 1-9 (2018).

360 distributions for naturally occurring isotopes. Biotechnol. Bioeng. 80, 477-479 (2002).

32. F. Matsuda, Y. Toya, H. Shimizu, Learning from quantitative data to understand central carbon metabolism. Biotechnol. Adv. 35, 971-980 (2017).

33. F. Matsuda, K. Maeda, T. Taniguchi, Y. Kondo, F. Yatabe, N. Okahashi, H. Shimizu, mfapy: An open-source Python package for flux analysis C-based metabolic. Metab. Eng.

365 Commun. 13, e00177 (2021).

34. I. Thiele, N. Swainston, R. M. T. Fleming, A. Hoppe, S. Sahoo, M. K. Aurich, H. Haraldsdottir, M. L. Mo, O. Rolfsson, M. D. Stobbe, S. G. Thorleifsson, R. Agren, C. Bölling, S. Bordel, A. K. Chavali, P. Dobson, W. B. Dunn, L. Endler, D. Hala, M. Hucka, D. Hull, D. Jameson, N. Jamshidi, J. J. Jonsson, N. Juty, S. Keating, I. Nookaew, N. Le Novère, N. Malys, 370 A. Mazein, J. A. Papin, N. D. Price, E. Selkov, M. I. Sigurdsson, E. Simeonidis, N. Sonnenschein, K. Smallbone, A. Sorokin, J. H. G. M. Van Beek, D. Weichart, I. Goryanin, J. Nielsen, H. V. Westerhoff, D. B. Kell, P. Mendes, B. O. Palsson, A community-driven global reconstruction of human metabolism. Nat. Biotechnol. 31, 419-425 (2013).

35. M. Popovic, Thermodynamic properties of microorganisms: determination and analysis 375 of enthalpy, entropy, and Gibbs free energy of biomass, cells and colonies of 32 microorganism species. Heliyon. 5, e01950 (2019). 
36. N. Okahashi, K. Maeda, S. Kawana, J. Iida, H. Shimizu, F. Matsuda, Sugar phosphate analysis with baseline separation and soft ionization by gas chromatography-negative chemical ionization-mass spectrometry improves flux estimation of bidirectional reactions in cancer cells. Metab. Eng. (2018).

37. E. Bianconi, A. Piovesan, F. Facchin, A. Beraudi, R. Casadei, F. Frabetti, L. Vitale, M. C. Pelleri, S. Tassani, F. Piva, S. Perez-Amodio, P. Strippoli, S. Canaider, An estimation of the number of cells in the human body. Ann. Hum. Biol. 40, 463-471 (2013).

38. L. Abas, M. A. Bogoyevitch, M. Guppy, Mitochondrial ATP production is necessary for activation of the extracellular-signal-regulated kinases during ischaemia/reperfusion in rat myocyte-derived H9c2 cells. Biochem. J. 349, 119-126 (2000).

39. A. I. Lutkin, V. V. Chernikov, O. N. Krutova, I. A. Skvortsov, Standard enthalpies of formation of l-lysine and the products of its dissociation in aqueous solutions. J. Therm. Anal. Calorim. 2017 1301. 130, 457-460 (2017). Ornithine and Products of Its Dissociation in Aqueous Solutions. Russ. J. Inorg. Chem. 63, 1112-1115 (2018).

Acknowledgments: We acknowledge the NGS core facility of the Genome Information Research Center at the Research Institute for Microbial Diseases, Osaka University for their support in RNA sequencing and data analysis. We thank Prof. Shinya Kuroda, Dr. Satoshi Ohno (University of Tokyo), and Shimpei Kawaoka (Kyoto University) for helpful comments on this manuscript. We also thank Keiko Fukamoto for her skillful technical support.

Funding: Grant-in-Aid for Scientific Research on Innovative Areas (Grant no. 17H06303).

\section{Author contributions:}

Conceptualization: NO, HS, CT, FM

Methodology: NO, HS, FM

Investigation: NO, TS, YK, CA, HU, ST, AS, SK

$405 \quad$ Funding acquisition: FM

Writing - original draft: NO, HS, CT, FM

Writing - review \& editing: NO, HS, CT, FM

Competing interests: Authors declare that they have no competing interests.

Data and materials availability: RNA-Seq data is available at DDBJ of the National Institute of Genetics (https:// www.ddbj.nig.ac.jp/index-e.html) via the index of DRA012975. 


\title{
Supplementary Materials
}

\section{Aerobic glycolysis in cancer cells supplies ATP while preventing excess metabolic thermogenesis}

\author{
Nobuyuki Okahashi ${ }^{1}$, Tomoki Shima ${ }^{1}$, Yuya Kondo ${ }^{1}$, Chie Araki ${ }^{1}$, Shuma Tsuji ${ }^{1}$, Akane Sawai ${ }^{1}$, Hikaru Uehara $^{1}$, \\ Susumu Kohno ${ }^{2}$, Hiroshi Shimizu ${ }^{1}$, Chiaki Takahashi ${ }^{2}$, and Fumio Matsuda ${ }^{1, *}$ \\ Correspondence to: fmatsuda@ist.osaka-u.ac.jp
}

\section{Materials and Methods}

Cell lines and culture condition

A total of 12 human cancer cell lines derived from colorectal cancer (HCT116, DLD-1, LS174T, WiDr), pancreatic cancer (MIA Paca-2, PANC-1), hepatoblastoma (HepG2), hepatocellular carcinoma (huH-1), breast cancer (MCF-7), renal cancer (Caki-1), glioblastoma (YKG-1), and sarcoma (HT1080) were obtained from the RIKEN Bioresource Research Center and JCRB Cell Bank. Culture experiments were performed as described previously (Okahashi et al., 2015). Briefly, $1.0 \times 10^{6}$ cells were seeded in $10 \mathrm{~mL}$ of Dulbecco's modified Eagle's medium (DMEM) supplemented with $10 \%$ fetal bovine serum (FBS) and $1 \%$ penicillin/streptomycin (Wako) in 100-mm (diameter) plates and cultured for $15 \mathrm{~h}$ at $37{ }^{\circ} \mathrm{C}$ under $5 \% \mathrm{CO}_{2}$. Additionally, ${ }^{13} \mathrm{C}$-labeling was performed in $10 \mathrm{~mL}$ of DMEM containing $20 \mathrm{mM}\left[1-{ }^{13} \mathrm{C}\right]$ glucose (Cambridge Isotope Laboratories, Andover, MA, USA, over 99\% purity) and 10\% dialyzed FBS (Life Technologies, Gaithersburg, MD, USA). The cells were counted non-invasively at $0,12,16,20$, and $24 \mathrm{~h}$ in triplicate cultures using a CKX53 microscope (Olympus, Tokyo, Japan) equipped with a DP22 digital camera (Olympus) and CKX-CCSW software (Olympus). Cell images were obtained at 10 different locations in the culture dish, after which the average cell numbers were used to generate the growth curve. Cultured media $(200 \mu \mathrm{L})$ were sampled at each time point. Trypsin was added to the plates and activated at $37{ }^{\circ} \mathrm{C}$ for 1 min to measure the diameter of the floating cells. After cell collection, the diameter of live cells was counted using trypan blue staining and a TC20 automated cell counter (BIO-RAD, Hercules, CA, USA).

\section{Extracellular metabolite measurements}

The collected culture medium was mixed with an equal volume of $20 \mathrm{mM}$ pimelate solution (internal standard) and filtered through a filter cartridge $(0.45-\mu \mathrm{m}$ pore size). Glucose, lactate, and acetate concentrations were determined by high-performance liquid chromatography (HPLC) equipped with a refractive index detector (Prominence, Shimadzu, Kyoto, Japan) and Aminex HPX-87H column (BIO-RAD) as previously described (Okahashi et al., 2015). Amino acid concentrations in the culture media were measured via HPLC using the AccQ•Tag method (Armenta et al., 2010). HPLC Prominence (Shimadzu) equipped with a Luna C18 (2) column 
(250 mm, $4.6 \mathrm{~mm}$, and $5.0 \mu \mathrm{m}$, SHIMADZU GLC, Kyoto, Japan) and a photodiode array detector $(260 \mathrm{~nm})$ was used. Derivatized amino acids were eluted with $20 \mathrm{mM}$ sodium acetate solution containing $0.04 \%(\mathrm{v} / \mathrm{v})$ trimethylamine and phosphate adjusted to $\mathrm{pH} 6.8(\mathrm{~A})$ and acetonitrile (B) under the following gradient conditions: 0 min $0 \%(B) ; 0.5 \mathrm{~min} 8 \%(\mathrm{~B}), 17.5 \mathrm{~min}$ $12 \%$ (B), $19 \min 15 \%$ (B), $20 \min 20 \%$ (B), $30.6 \min 100 \%$ (B), and $33.1 \mathrm{~min} 0 \%$ (B) at a flow rate of $1.0 \mathrm{~mL} / \mathrm{min}$. The column oven temperature was maintained at $40{ }^{\circ} \mathrm{C}$.

\section{Extraction and derivatization of intracellular metabolites}

465 Intracellular metabolites were extracted using a methanol/water/chloroform method (Okahashi et al., 2015). Cellular metabolites were rapidly quenched by adding $800 \mu \mathrm{L}$ of precooled methanol after rapid medium removal and rinsing with PBS $(1 \mathrm{~mL})$. This procedure was performed within $15 \mathrm{~s}$. The cells and solution were collected by scraping. Cell lysates were transferred into fresh sample tubes, and $800 \mu \mathrm{L}$ of cold chloroform and $320 \mu \mathrm{L}$ of cold water were added. After vortexing and centrifugation, $250 \mu \mathrm{L}$ of the upper aqueous layer was collected and dried in a vacuum concentrating centrifuge (CVE-3110, Eyela, Tokyo, Japan) at room temperature. The dried metabolites were methoxyaminated and tert-butyldimethylsilyated for GC-MS analysis, as described previously (Araki et al., 2018).

Gas chromatography/mass spectrometry analysis

Gas chromatography/mass spectrometry (GC/MS) analysis was performed using a GCMSQP2020 (Shimadzu) equipped with a DB-5MS capillary column (Agilent Technologies). GC/MS was operated under electron impact (EI) ionization at 70 electron volts $(\mathrm{eV})$. One microliter of the sample was injected at $250{ }^{\circ} \mathrm{C}$ using helium as the carrier gas at a flow rate of $1 \mathrm{ml} / \mathrm{min}$. To analyze central metabolite derivatives, the GC oven temperature was held at $60{ }^{\circ} \mathrm{C}$, increased to $325^{\circ} \mathrm{C}$ at $10^{\circ} \mathrm{C} / \mathrm{min}$ for a total run time of approximately $30 \mathrm{~min}$. The MS source and quadrupole were held at $230{ }^{\circ} \mathrm{C}$ and $150{ }^{\circ} \mathrm{C}$, respectively. The ions were monitored in the selected ion monitoring mode. The effect of naturally occurring isotopes has been eliminated (van Winden et al., 2002).

${ }^{13} \mathrm{C}$-metabolic flux analysis and mass balance analysis

Specific uptake and secretion rates of extracellular metabolites were calculated as previously described (Matsuda et al., 2017). Metabolic flux distribution was estimated by minimizing the variance-weighted residual sum of squares of measured and estimated mass isotopomer distributions of intracellular metabolites and effluxes using mfapy (Matsuda et al., 2021). ATP production through the Embden-Meyerhof-Parnas pathway and TCA cycle. ATP consumption during glucose uptake and the phosphofructokinase reaction were calculated using the estimated metabolic flux distribution.

The net ATP regeneration flux was calculated using flux distributions and the following assumptions: the reactions catalyzed by hexokinase, phosphofructokinase, pyruvate carboxylase, and acetyl-coenzyme A citrate lyase/phosphoglycerate kinase, pyruvate kinase, and succinylcoenzyme A lyase were assumed to be ATP consuming/regenerating reactions, respectively. NADPH was also assumed to be regenerated in reactions involving glucose 6-phosphate dehydrogenase, 6-phosphogluconate dehydrogenase, isocitrate dehydrogenase, and malate $\mathrm{NADP}^{+}$oxidoreductase, and NADPH was consumed in the fatty acid and proline biosynthesis pathways. Excess NADPH was assumed to be converted to NADH via a transhydrogenase reaction. NADH was regenerated in reactions involving glyceraldehyde-3 phosphate dehydrogenase, pyruvate dehydrogenase, alpha-ketoglutarate dehydrogenase, malate dehydrogenase, and transhydrogenase reactions and is consumed by lactate dehydrogenase. 
Excess NADH was assumed to be converted to ATP via OXPHOS. The P/O ratio was assumed to be 2.5. Although $\mathrm{FADH}_{2}$ was also converted to ATP in OXPHOS, its P/O ratio was assumed to be 1.5 . The ATP required for cell biomass synthesis was assumed to be $35 \mathrm{mmol} / \mathrm{g}$ dry cell weight (Thiele et al., 2013).

The gene expression dataset (E-MTAB-2706) of cancer cell lines was obtained from ArrayExpress (https://www.ebi.ac.uk/arrayexpress/) (Klijn et al., 2015). The genes related to central metabolism were obtained from the KEGG pathway database (glycolysis/gluconeogenesis, pentose phosphate pathway, citrate cycle, D-glutamine and Dglutamate metabolism, and related transporters). The 62 genes were selected as there were no missing data in the dataset. The TPM-normalized, log2-transformed, and Z-scored gene expression datasets of 622 cancer cell lines were used for hierarchical clustering using the Seaborn clustermap of Python 3.8 (the Ward method combined with the Euclidean distance).

\section{$\underline{\text { Flux balance analysis }}$}

A human genome scale model (RECON2) (Thiele et al., 2013) was used with the following modifications: i) 41 reactions responsible for the degradation of essential amino acids were removed from the model, ii) terms of standard enthalpy of formation $\left(\mathrm{MegaJ} \mathrm{mol}^{-1}\right)$ were added to intra/extracellular transport reactions (Tables S7 and S8), and iii) the reaction (R_ent) was added to the sum of the standard enthalpy of formation. Metabolic heat dissipation (hout) was calculated using the following equation:

$$
h_{\text {out }}=-\left(\sum_{i} \Delta_{f}{H^{\prime}}_{i}^{0} J_{i}-\sum_{j} \Delta_{f} H_{j}^{\prime 0} J_{j}\right)
$$

$530 \quad$ Here, $J i$ and $J j$ indicate the uptake and excretion flux levels of the $i$ th and $j$ th metabolites, respectively. Moreover, $\Delta_{\mathrm{f}} H^{0}$ is the standard enthalpy of formation of each metabolite; $\Delta_{\mathrm{f}} H^{0}$ values at $\mathrm{pH} 7.0$ and ion strength $=0.1 \mathrm{M}$ were obtained from published literature (Alberty, 1998). The $\Delta_{\mathrm{f}} H^{\prime}{ }^{0}$ level of biomass was approximated based on data from experiments on yeast (Popovic, 2019). The approximation does not affect FBA in this study because the metabolic flux 535 levels for biomass synthesis were fixed to the measured values. FBA was performed using an inhouse Python script using GLPK in the pulp module as a linear programming solver.

\section{RNA-sequencing}

Total RNA was extracted using QIAzol lysis reagent (QIAGEN). Library preparation was performed using a TruSeq stranded mRNA sample prep kit (Illumina, San Diego, CA, USA) according to the manufacturer's instructions. Sequencing was performed on an Illumina HiSeq 3000 platform in a $101 \mathrm{bp}$ single-end mode. Illumina Casava1.8.2 software was used for base calling. Sequenced reads were mapped to the human reference genome sequences (hg19) using TopHat v2.0.13 in combination with Bowtie2 ver. 2.2.3 and SAMtools ver. 0.1.19. The fragments per kilobase of exon per million mapped fragments (FPKMs) were calculated using Cufflinks version 2.2.1. Gene enrichment analysis was performed using the Enrichr web tool (Xie et al., 2021). 


\section{Supplementary Text}

Text S1 Detailed explanation of the ${ }^{13} \mathrm{C}$-metabolic flux analysis procedure

The metabolic model consisted of the major pathways of central carbon metabolism, including glycolysis, the pentose phosphate pathway, the TCA cycle, anaplerotic reactions, and biomass synthesis (Table S8). Folate metabolism was ignored, as MTHFD1 and MTHFD2 were not highly expressed (Figure S2). The catabolism of the essential amino acids was ignored. Biomass effluxes of amino acids for proteins, glucose-6-phosphate for glycogen, ribose-5phosphate for ribonucleic acid, and cytosolic acetyl-CoA for fatty acids were calculated from the specific growth rates and biomass compositions of mammalian cells (Okahashi et al., 2018). The constant for the conversion from cell number to dry cell weight was assumed to be 0.392 mg-dry cell weight $\left(10^{6} \text { cells }\right)^{-1}$ for all cell lines (Okahashi et al., 2018). This assumption was based on the observation that the detached cell sizes from culture dishes were almost identical to all cell lines except for Caki-1 (Table S1). Additionally, the effect of this assumption on the total metabolic flux was considered to be minor because the effluxes for biomass synthesis accounted for only a minor percentage of carbon uptake flux. The goodness of fit of ${ }^{13} \mathrm{C}-\mathrm{MFA}$ was evaluated by $\chi^{2}$ statistics test, where the standard deviations of ${ }^{13} \mathrm{C}$-labeling were assumed to be 0.01 (Araki et al., 2018). The ${ }^{13} \mathrm{C}$-MFA of all cultured cancer cell lines successfully passed the $\chi^{2}$-test (Table S2). All 95\% confidence intervals were determined using the grid search method and are shown in Table S2 (Okahashi et al., 2018)(Antoniewicz et al., 2006)(Antoniewicz et al., 570 2006).

Text S2 Comparison of the net ATP regeneration rate in cultured cancer cells with that of normal $\underline{\text { cells }}$

In this study, the net ATP regeneration rate of MCF-7 cells was determined as $1815 \mathrm{nmol}$ $\left(10^{6} \text { cells }\right)^{-1} \mathrm{~h}^{-1}$ based on the metabolic flux distribution (Fig. 1a). The net ATP regeneration rates ranged from 1460 (LS174T) to $4086\left(\right.$ Caki-1) nmol $\left(10^{6} \text { cells }\right)^{-1} \mathrm{~h}^{-1}$ among the 12 cell lines. The total human cell number is $3.72 \times 10^{13}$, composed of $15 \%$ non-erythrocyte cells (Bianconi et al., 2013). Moreover, ATP was presumed to be regenerated by OXPHOS using glucose (32 ATP/glucose). If all non-erythrocyte cells reproduce ATP at the same level of LS174T, the required amount of glucose $\left(\mathrm{g} \mathrm{day}^{-1}\right)$ is $1460 \times 10^{-9} \mathrm{nmol}\left(10^{-6} \text { cells }\right)^{-1} \mathrm{~h}^{-1} \times 24 \mathrm{~h} \times 3.72 \times 10^{13}$ cells $\times 0.15 \times 1 / 32$ (glucose/ATP) $\times 180 \mathrm{~g} \mathrm{~mol}^{-1}=1100 \mathrm{~g} \mathrm{day}^{-1}$, equal to $3686 \mathrm{kcal} \mathrm{day}^{-1}$. The recommended daily calorie intake is 2,000 and 2,500 kcal day ${ }^{-1}$ for women and men, respectively, suggesting that the ATP regeneration level of MCF-7 cells was higher than that of normal cells.

Moreover, the metabolic flux conducted in this study revealed that the ATP regeneration rates by OXPHOS in 12 cancer cells were $447-1727 \mathrm{nmol}\left(10^{6} \text { cells }\right)^{-1} \mathrm{~h}^{-1}$. If the glucose equivalent of 2,500 $\mathrm{kcal} \mathrm{day}^{-1}$ were catabolized to produce ATP by OXPHOS, the net ATP regeneration rate would be $994 \mathrm{nmol}\left(10^{6} \text { cells }\right)^{-1} \mathrm{~h}^{-1}$. This level is similar to reported data such as that of rat heart H9c2 (normal) cells $\left(1282.5 \mathrm{nmol}\left(10^{6} \text { cells }\right)^{-1} \mathrm{~h}^{-1}\right)($ Abas et al., 2000). 
Figure S1. Metabolic flux distribution of 12 cancer cell lines as determined by ${ }^{13} \mathrm{C}-\mathrm{MFA}$. All the values represent the metabolic flux level $\left(\mathrm{nmol}\left(10^{6} \text { cells }\right)^{-1} \mathrm{~h}^{-1}\right)$. Measured specific cell proliferation rate $\left(\mu\left[\mathrm{h}^{-1}\right]\right)$ and cell adhesion area (cell area $\left.\left[\mu \mathrm{m}^{2}\right]\right)$, as well as the ATP regeneration rates by OXPHOS, substrate-level phosphorylation, and the net ATP regeneration rate are shown in the figure.

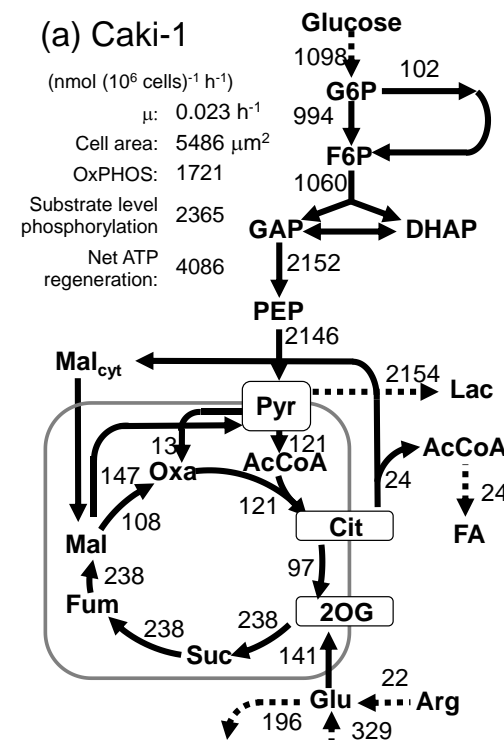

Glu, Pro, Orn Gìn
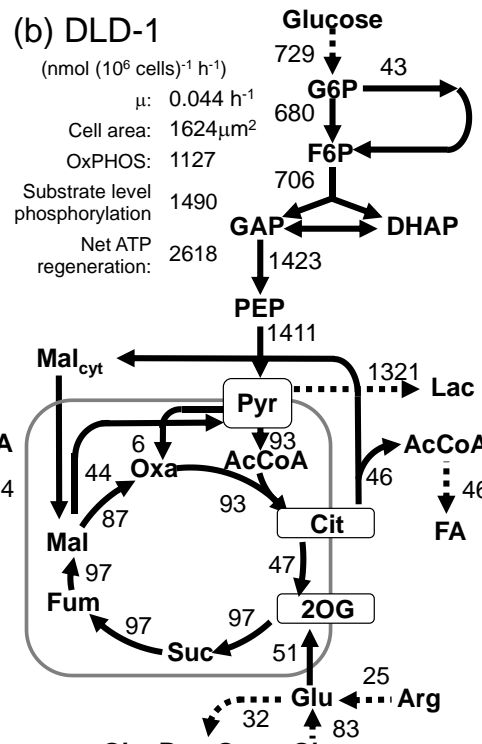

Glu, Pro, Orn Gïn (c) HCT116 Gluçose

(nmol $\left.\left(10^{6} \text { cells }\right)^{-1} h^{-1}\right) \quad 417$

$\mu: 0.031 \mathrm{~h}^{-1}$

Cell area: $645 \mu \mathrm{m}^{2}$

OxPHOS: 794

Substrate level 881

Net ATP
nosphory

Net ATP
regeneration:

1674

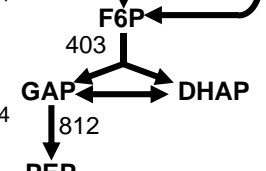

(d) HepG2

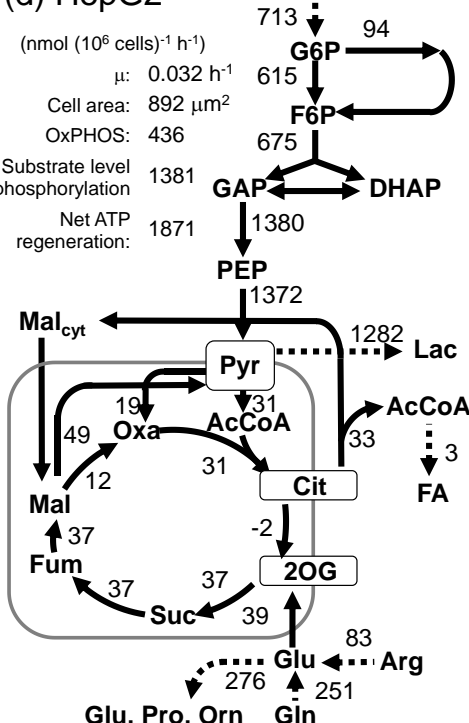

(e) HT1080 Gluçose

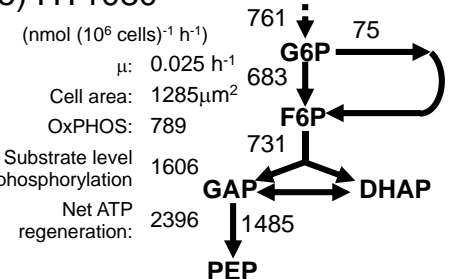

$\mathrm{Mal}_{\text {cyt }} \longleftarrow 1511$

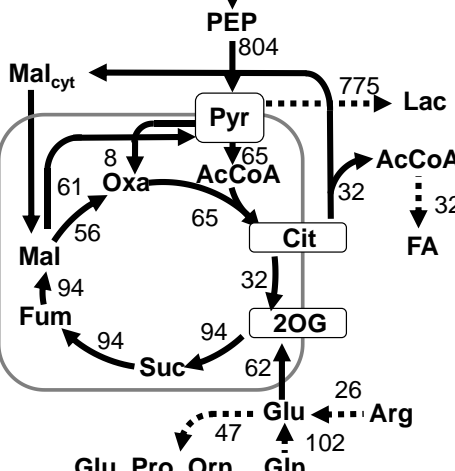

Glu, Pro, Orn Gîn (f) huH-1 Gluçose

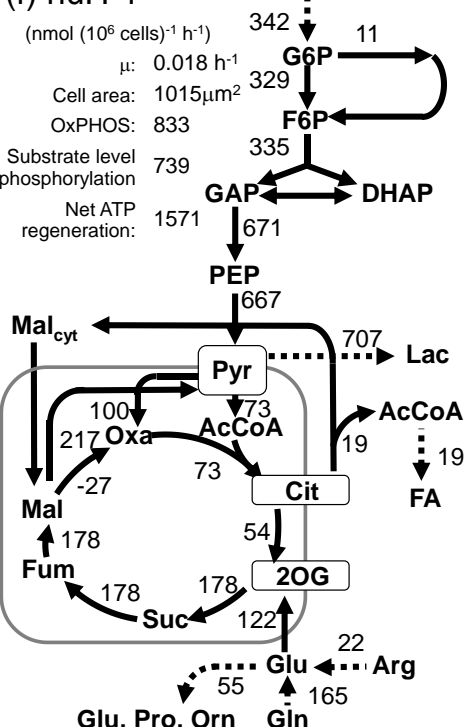


Figure S1. (continued) Metabolic flux distribution of 12 cancer cell lines as determined by ${ }^{13} \mathrm{C}$ MFA. All values represent metabolic flux level (nmol $\left.\left(10^{6} \text { cells }\right)^{-1} \mathrm{~h}^{-1}\right)$.

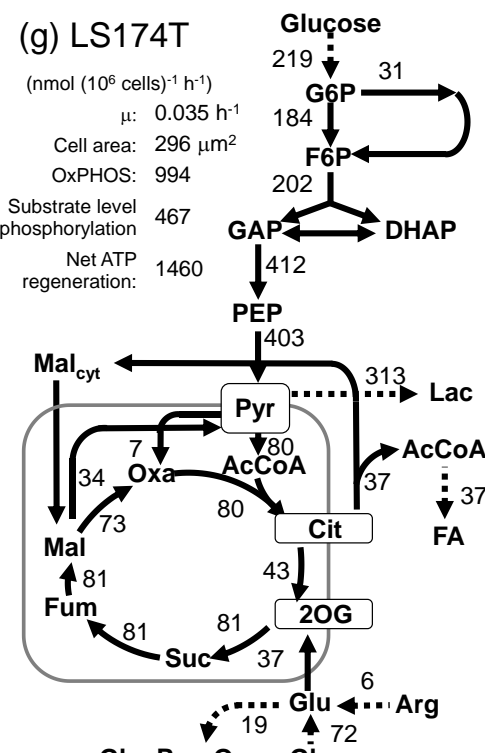

Glu, Pro, Orn Gin (h) MCF-7 Gluçose
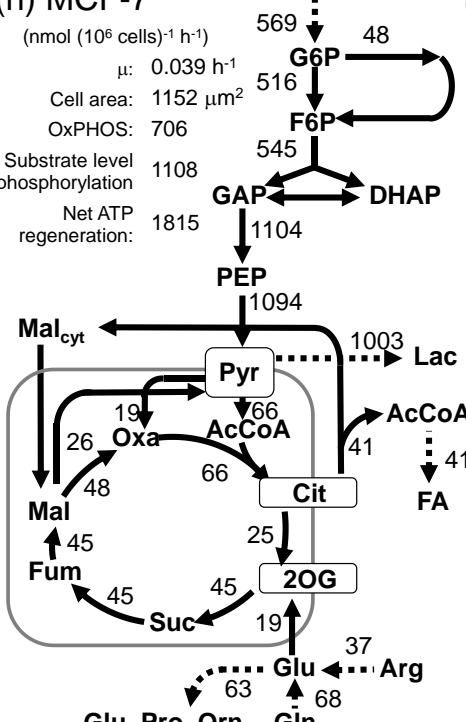

Glu, Pro, Orn Gin
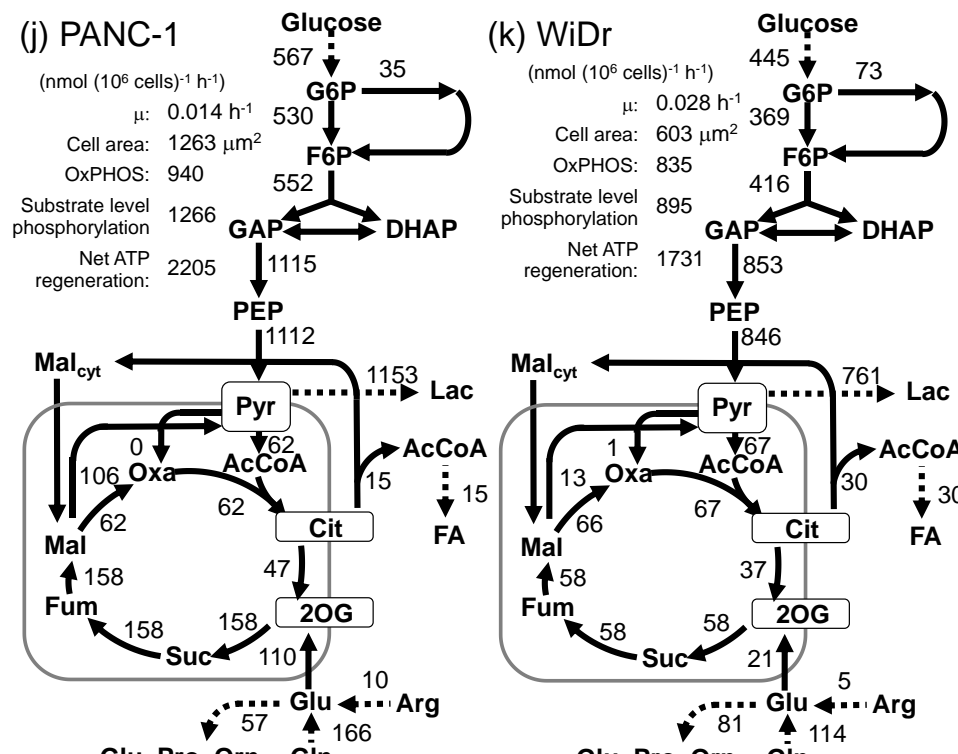

Glu, Pro, Orn Gìn

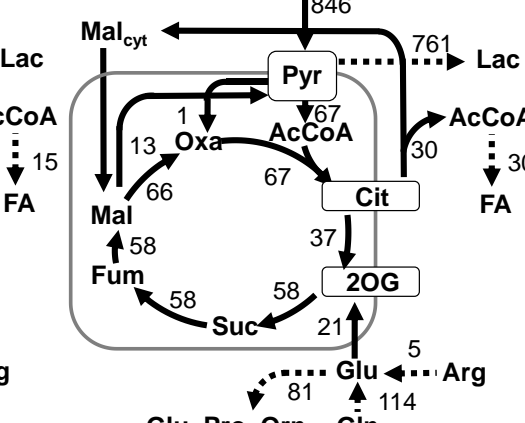

Glu, Pro, Orn Gìn (i) MIA Paca-2 Gluçose
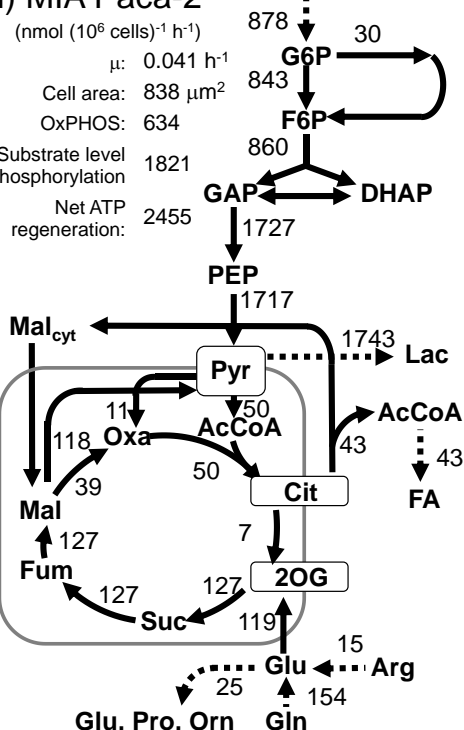

Glu, Pro, Orn Gin

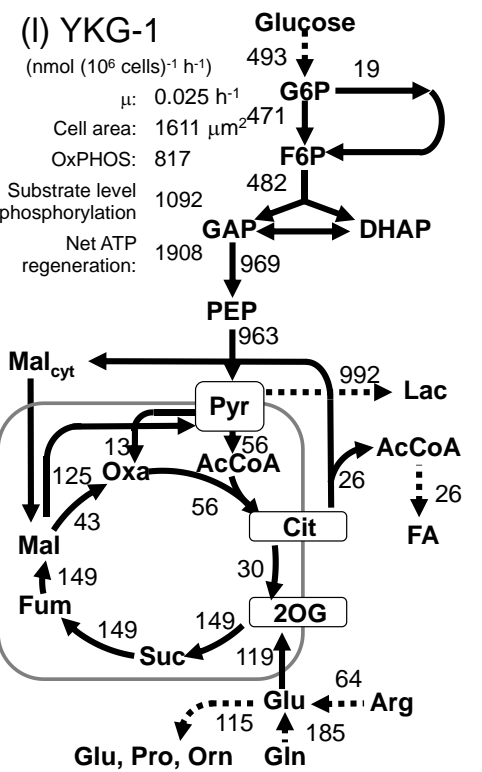

605 
Figure S2. Hierarchical clustering of 622 cancer cell line using publicly available expression data of 62 central metabolism-related genes (Klijn et al., 2015). 62 central metabolism-related genes were obtained from the Kegg pathway database and selected due to there being no missing data in the dataset. For hierarchical clustering, the Ward method combined with the Euclidean distance was used. From each cluster, colorectal cancer (HCT116, DLD-1, LS174T, WiDr), pancreatic cancer (MIA Paca-2, PANC-1), hepatoblastoma (HepG2), hepatocellular carcinoma (huH-1), breast cancer (MCF-7), renal cancer (Caki-1), and sarcoma (HT1080) were selected. Moreover, glioblastoma (YKG-1) was arbitrarily selected for the analysis. The ability to grow in Dulbecco's modified Eagle's medium (DMEM) was also considered to reduce a bias from 615 culture conditions.

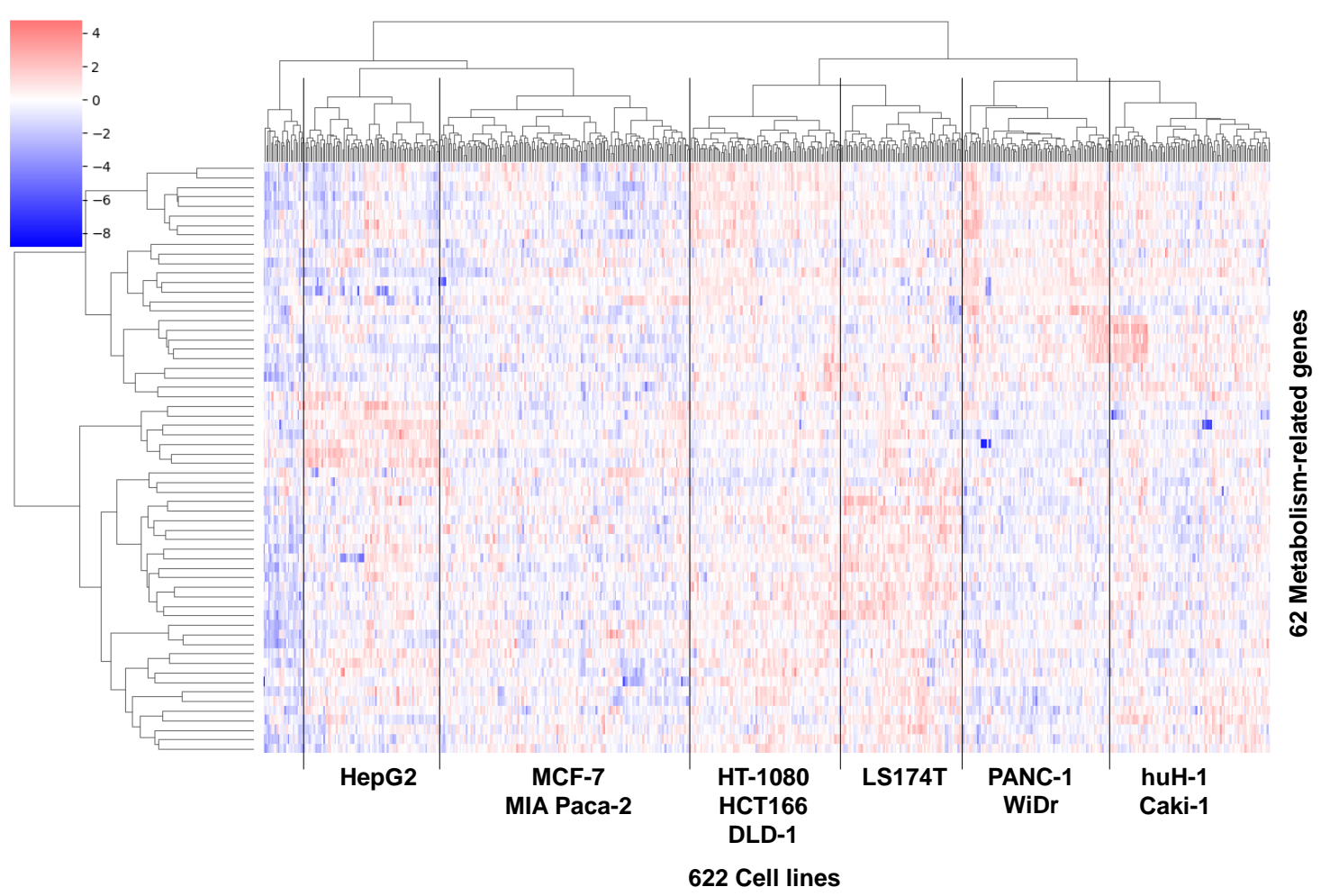


Figure S3. Variations in flux levels of (a) GAPDH, (b) GLUDH and IDH reactions, and (c) ATP regeneration rates by substrate-level phosphorylation and OXPHOS. Error bars represent $95 \%$ confidence intervals.

(a)

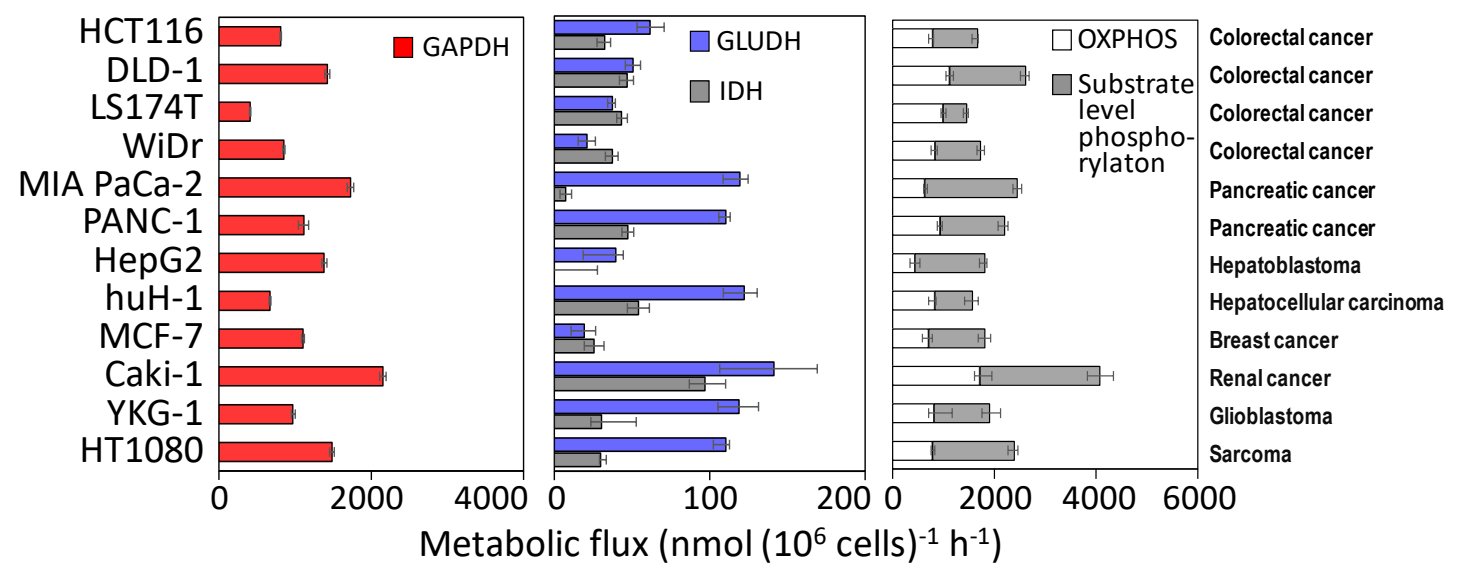


bioRxiv preprint doi: https://doi.org/10.1101/2021.11.16.468557; this version posted November 19,2021 . The copyright holder for this preprint (which was not certified by peer review) is the author/funder, who has granted bioRxiv a license to display the preprint in perpetuity. It is made available under aCC-BY-ND 4.0 International license.

Figure S4. Scatter plots among the ATP regeneration rates and the visible phenotype data. Spearman's rank order correlation coefficients were also shown.

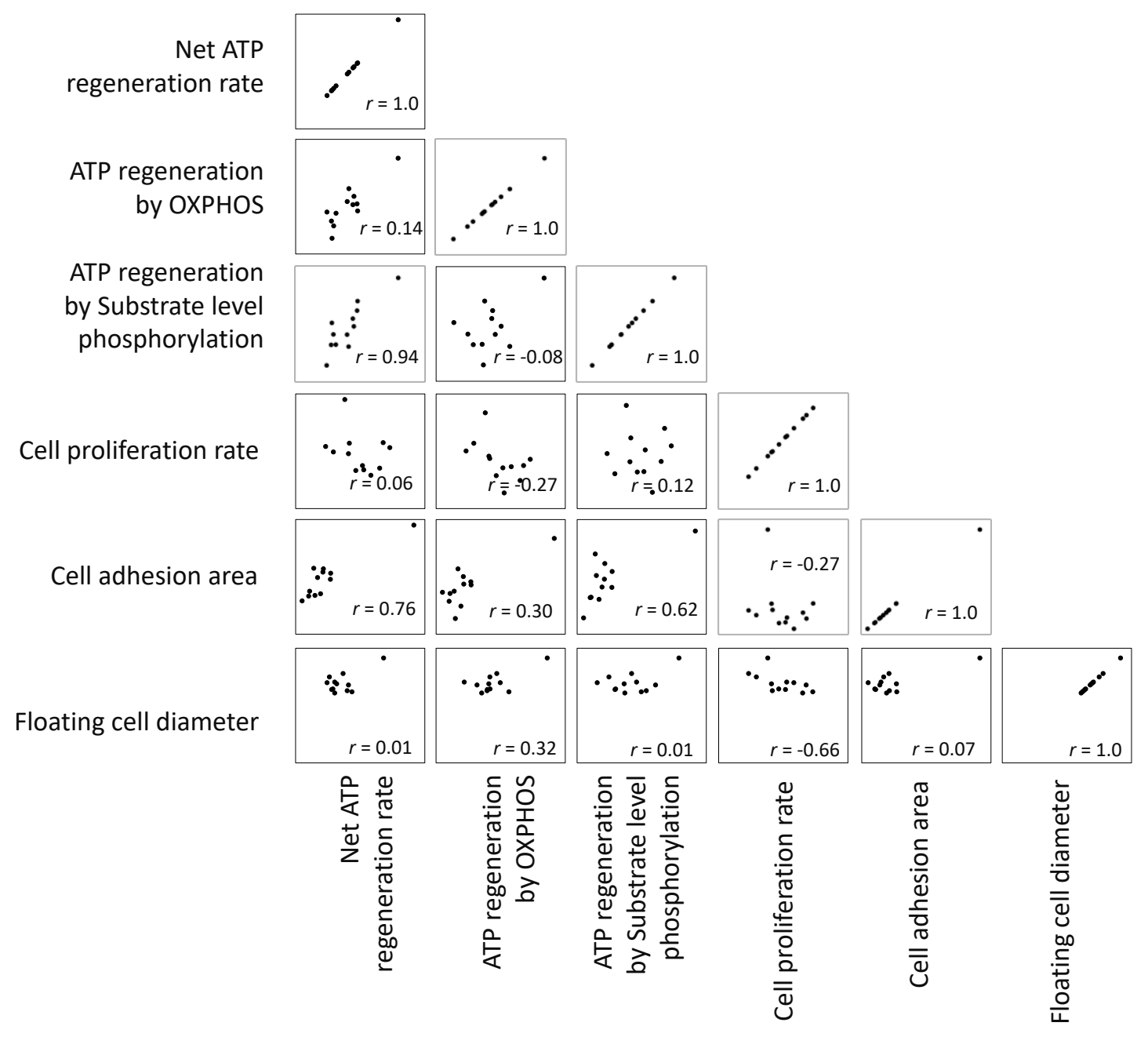

630 
Figure S5. Correlation among ATP regeneration rates and the visible phenotypes in the cell upon removal of the outlier cell line (Caki-1) from the dataset. Spearman's rank order correlation coefficients are shown in the heat map $(n=11)$.

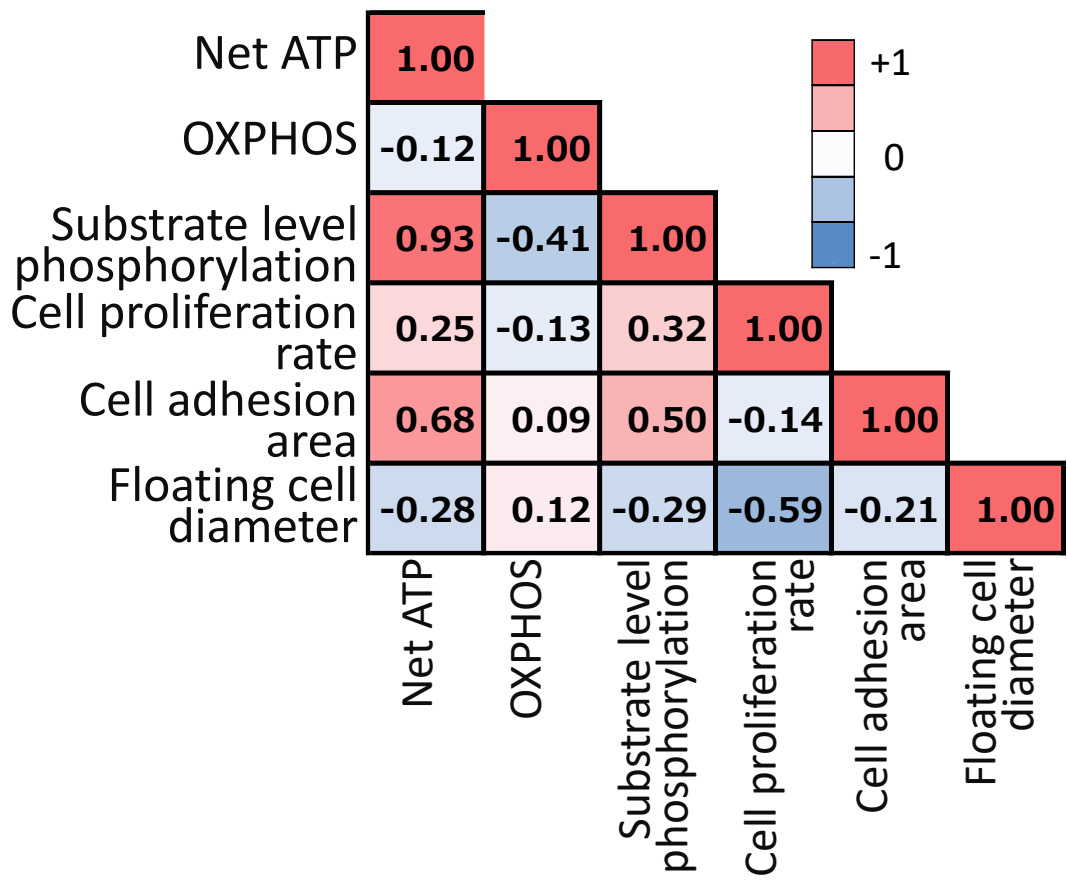


Figure S6. Mitochondrial membrane potential is retained in cultured cancer cells. The potentialdependent dye, JC-1, was used to monitor the mitochondrial membrane potential.

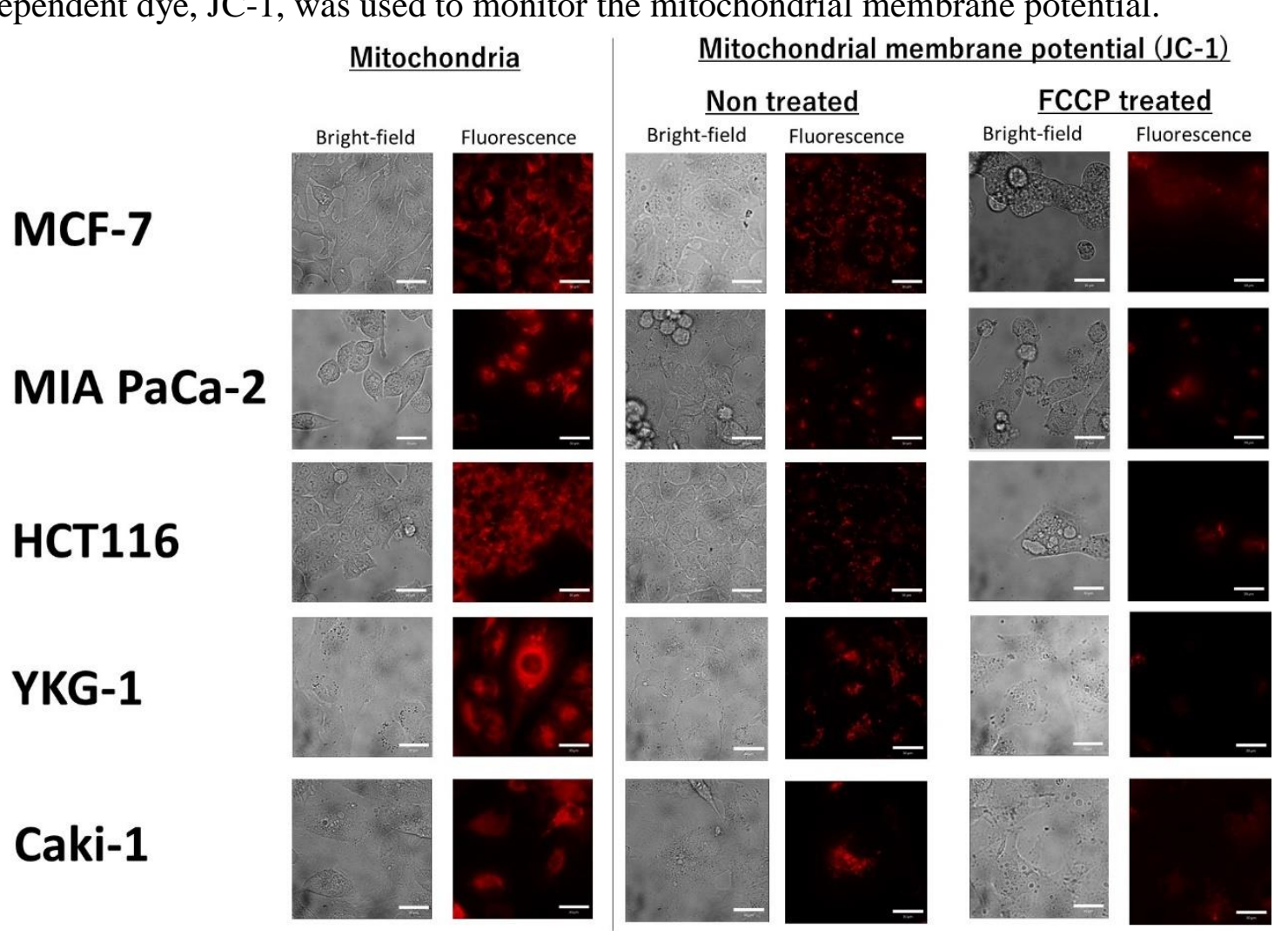


Figure S7. Comparison of predicted metabolic flux distributions by flux balance analysis (FBA) (x-axis) and estimated metabolic flux data (y-axis) for 12 cell lines. In silico simulation of metabolism was performed by FBA using a genome scale model of human metabolism (RECON2).
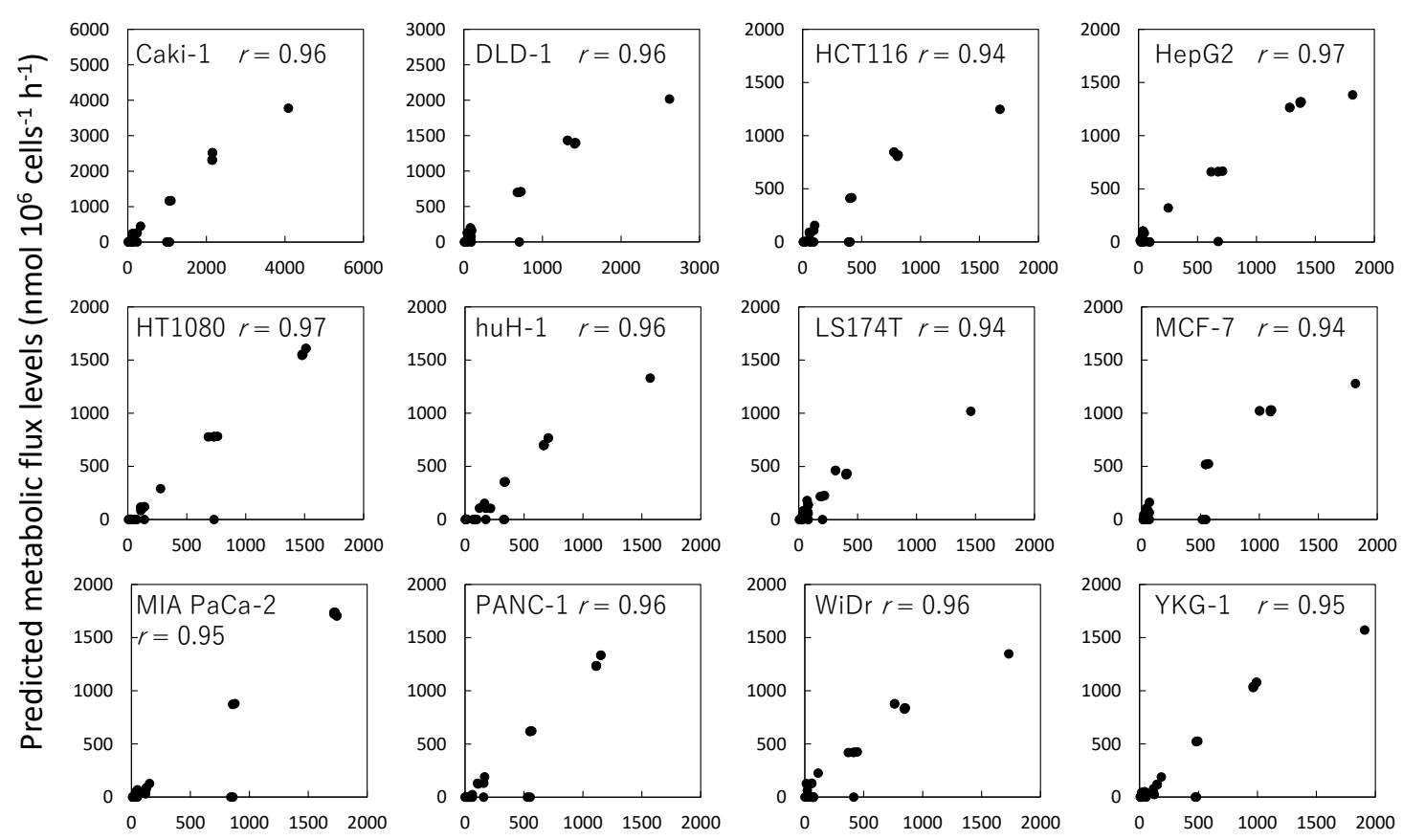

Measured metabolic flux levels ( $\mathrm{nmol} 10^{6}$ cells $^{-1} \mathrm{~h}^{-1}$ ) 
Table S1 Culture profiles of 12 cell lines

\begin{tabular}{|c|c|c|c|c|c|c|c|}
\hline Measured & Unit & Caki-1 & DLD-1 & HCT116 & HepG2 & HT-1080 & Huh-1 \\
\hline $\begin{array}{l}\text { Specific } \\
\text { cell } \\
\text { growth } \\
\text { rate }(\mathrm{mu})\end{array}$ & $\mathrm{h}^{-1}$ & 0.0228 & 0.0437 & 0.031 & 0.0316 & 0.0249 & 0.0175 \\
\hline $\begin{array}{l}\text { cell } \\
\text { adhesion } \\
\text { area }\end{array}$ & $\begin{array}{l}\mu \mathrm{m}^{2}(\mathrm{n}= \\
30)\end{array}$ & $\begin{array}{l}3486 \pm \\
792\end{array}$ & $\begin{array}{l}1623 \pm \\
468\end{array}$ & $\begin{array}{l}645 \pm \\
159\end{array}$ & $\begin{array}{l}891 \pm \\
300\end{array}$ & $\begin{array}{l}1284 \pm \\
533\end{array}$ & $\begin{array}{l}1015 \pm \\
322\end{array}$ \\
\hline $\begin{array}{l}\text { Diameter } \\
\text { of floating } \\
\text { cells }\end{array}$ & $\begin{array}{l}\mu \mathrm{m}(\mathrm{N}= \\
56-595)\end{array}$ & $\begin{array}{l}18.3 \pm \\
3.7\end{array}$ & $\begin{array}{l}12.4 \pm \\
2.2\end{array}$ & $\begin{array}{l}12.8 \pm \\
1.5\end{array}$ & $\begin{array}{l}14.1 \pm \\
1.5\end{array}$ & $\begin{array}{l}12.6 \pm \\
1.9\end{array}$ & $\begin{array}{l}15.0 \pm \\
2.0\end{array}$ \\
\hline $\begin{array}{l}\text { Glucose } \\
\text { uptake }\end{array}$ & $\begin{array}{l}\text { nmol } \\
\left(10^{6}\right. \\
\text { cells })^{-1} \mathrm{~h}^{-} \\
1\end{array}$ & $\begin{array}{l}606 \pm \\
232\end{array}$ & $\begin{array}{l}742 \pm \\
32.0\end{array}$ & $\begin{array}{l}361 \pm \\
17.0\end{array}$ & $\begin{array}{l}755 \pm \\
250\end{array}$ & $\begin{array}{l}604 \pm \\
75.8\end{array}$ & $\begin{array}{l}397 \pm \\
45.0\end{array}$ \\
\hline $\begin{array}{l}\text { Glutamine } \\
\text { uptake }\end{array}$ & $\begin{array}{l}\text { nmol } \\
\left(10^{6}\right. \\
\text { cells })^{-1} \mathrm{~h}^{-} \\
1\end{array}$ & $327 \pm 30$ & $84 \pm 4.8$ & $98 \pm 5.3$ & $\begin{array}{l}295 \pm \\
46\end{array}$ & $\begin{array}{l}278 \pm \\
7.07\end{array}$ & $168 \pm 9.3$ \\
\hline $\begin{array}{l}\text { Arginine } \\
\text { uptake }\end{array}$ & $\begin{array}{l}\text { nmol } \\
\left(10^{6}\right. \\
\text { cells })^{-1} \mathrm{~h}^{-} \\
1\end{array}$ & $22 \pm 2$ & $25 \pm 1.2$ & $25 \pm 1.2$ & $84 \pm 6$ & $\begin{array}{l}56.9 \pm \\
2.78\end{array}$ & $22 \pm 2.2$ \\
\hline $\begin{array}{l}\text { Valine } \\
\text { uptake }\end{array}$ & $\begin{array}{l}\mathrm{nmol} \\
\left(10^{6}\right. \\
\text { cells })^{-1} \mathrm{~h}^{-} \\
1\end{array}$ & $\begin{array}{l}-32.9 \pm \\
21.3\end{array}$ & $7 \pm 0.7$ & $5 \pm 1.6$ & $66 \pm 26$ & $8.5 \pm 4.8$ & $\begin{array}{l}13.6 \pm \\
2.8\end{array}$ \\
\hline $\begin{array}{l}\text { Leucine } \\
\text { uptake }\end{array}$ & $\begin{array}{l}\text { nmol } \\
\left(10^{6}\right. \\
\text { cells })^{-1} \mathrm{~h}^{-} \\
1\end{array}$ & $\begin{array}{l}4.2 \pm \\
17.2\end{array}$ & $16 \pm 0.5$ & $12 \pm 1.9$ & $76 \pm 22$ & $\begin{array}{l}22.2 \pm \\
4.9\end{array}$ & $\begin{array}{l}17.5 \pm \\
2.0\end{array}$ \\
\hline $\begin{array}{l}\text { Isoleucine } \\
\text { uptake }\end{array}$ & $\begin{array}{l}\text { nmol } \\
\left(10^{6}\right. \\
\text { cells })^{-1} \mathrm{~h}^{-} \\
1\end{array}$ & $\begin{array}{l}-24.4 \pm \\
22.5\end{array}$ & $9.4 \pm 0.4$ & $\begin{array}{l}13.9 \pm \\
2.7\end{array}$ & $76 \pm 22$ & $\begin{array}{l}17.5 \pm \\
5.2\end{array}$ & $\begin{array}{l}32.9 \pm \\
5.3\end{array}$ \\
\hline $\begin{array}{l}\text { Lactate } \\
\text { excretion }\end{array}$ & $\begin{array}{l}\mathrm{nmol} \\
\left(10^{6}\right. \\
\text { cells })^{-1} \mathrm{~h}^{-} \\
1\end{array}$ & $\begin{array}{l}2158 \pm \\
27\end{array}$ & $\begin{array}{l}1311 \pm \\
40\end{array}$ & $776 \pm 3$ & $\begin{array}{l}1282 \pm \\
29\end{array}$ & $\begin{array}{l}1514 \pm \\
13.0\end{array}$ & $708 \pm 3$ \\
\hline $\begin{array}{l}\text { Glutamate } \\
\text { excretion }\end{array}$ & $\begin{array}{l}\text { nmol } \\
\left(10^{6}\right. \\
\text { cells })^{-1} \mathrm{~h}^{-} \\
1\end{array}$ & $143 \pm 5$ & $1 \pm 1$ & $22 \pm 0$ & $\begin{array}{l}132 \pm \\
14\end{array}$ & $\begin{array}{l}133 \pm \\
2.96\end{array}$ & $43 \pm 2$ \\
\hline
\end{tabular}




\begin{tabular}{|c|c|c|c|c|c|c|c|}
\hline $\begin{array}{l}\text { Alanine } \\
\text { excretion }\end{array}$ & $\begin{array}{l}\text { nmol } \\
\left(10^{6}\right. \\
\text { cells })^{-1} h^{-} \\
\end{array}$ & $0 \pm 0$ & $\begin{array}{l}23.2 \pm \\
1.3\end{array}$ & $\begin{array}{l}8.8 \pm \\
0.2\end{array}$ & $80 \pm 7$ & $\begin{array}{l}7.14 \pm \\
0.317\end{array}$ & $0.0 \pm 0.0$ \\
\hline $\begin{array}{l}\text { Proline } \\
\text { excretion }\end{array}$ & $\begin{array}{l}\text { nmol } \\
\left(10^{6}\right. \\
\text { cells })^{-1} \mathrm{~h}^{-} \\
1\end{array}$ & $\begin{array}{l}34.6 \pm \\
0.4\end{array}$ & $9.2 \pm 0.5$ & $\begin{array}{l}1.7 \pm \\
0.1\end{array}$ & $21 \pm 2$ & $\begin{array}{l}12.4 \pm \\
0.472\end{array}$ & $5.4 \pm 0.3$ \\
\hline $\begin{array}{l}\text { Ornithine } \\
\text { excretion }\end{array}$ & $\begin{array}{l}\text { nmol } \\
\left(10^{6}\right. \\
\text { cells })^{-1} h^{-} \\
\end{array}$ & $\begin{array}{l}18.2 \pm \\
3.03\end{array}$ & $\begin{array}{l}21.9 \pm \\
1.2\end{array}$ & $\begin{array}{l}23.9 \pm \\
0.7\end{array}$ & $\begin{array}{l}112 \pm \\
19\end{array}$ & $\begin{array}{l}62.9 \pm \\
2.6\end{array}$ & $6.4 \pm 1$ \\
\hline
\end{tabular}

\begin{tabular}{|c|c|c|c|c|c|c|c|}
\hline Measured & Unit & LS174T & MCF7 & $\begin{array}{l}\text { MIAPACA } \\
2\end{array}$ & Panc-1 & WiDr & YKG-1 \\
\hline $\begin{array}{l}\text { Specific } \\
\text { cell } \\
\text { growth } \\
\text { rate }(\mathrm{mu})\end{array}$ & $\mathrm{h}^{-1}$ & 0.0349 & 0.039 & 0.0406 & 0.0139 & 0.0279 & 0.0245 \\
\hline $\begin{array}{l}\text { cell } \\
\text { adhesion } \\
\text { area }\end{array}$ & $\begin{array}{l}\mu \mathrm{m}^{2}(\mathrm{n}= \\
30)\end{array}$ & $296 \pm 93$ & $\begin{array}{l}1152 \pm \\
372\end{array}$ & $838 \pm 174$ & $\begin{array}{l}1263 \pm \\
405\end{array}$ & $\begin{array}{l}603 \pm \\
196\end{array}$ & $\begin{array}{l}1611 \pm \\
588\end{array}$ \\
\hline $\begin{array}{l}\text { Diameter } \\
\text { of floating } \\
\text { cells }\end{array}$ & $\begin{array}{l}\mu \mathrm{m}(\mathrm{N}= \\
56-595)\end{array}$ & $\begin{array}{l}14.0 \pm \\
2.0\end{array}$ & $\begin{array}{l}12.2 \pm \\
1.8\end{array}$ & $13.6 \pm 1.8$ & $\begin{array}{l}15.6 \pm \\
2.1\end{array}$ & $\begin{array}{l}12.9 \pm \\
1.6\end{array}$ & $\begin{array}{l}13.8 \pm \\
1.4\end{array}$ \\
\hline $\begin{array}{l}\text { Glucose } \\
\text { uptake }\end{array}$ & $\begin{array}{l}\text { nmol } \\
\left(10^{6}\right. \\
\text { cells })^{-1} \mathrm{~h}^{-} \\
1\end{array}$ & $\begin{array}{l}222 \pm \\
21.0\end{array}$ & $507 \pm 9.9$ & $1031 \pm 81.7$ & $\begin{array}{l}538 \pm \\
133.5\end{array}$ & $\begin{array}{l}481 \pm \\
37.0\end{array}$ & $\begin{array}{l}400 \pm \\
43.98\end{array}$ \\
\hline $\begin{array}{l}\text { Glutamine } \\
\text { uptake }\end{array}$ & $\begin{array}{l}\text { nmol } \\
\left(10^{6}\right. \\
\text { cells })^{-1} \mathrm{~h}^{-} \\
1\end{array}$ & $75 \pm 2.7$ & $66 \pm 5.0$ & $156 \pm 7.1$ & $\begin{array}{l}167 \pm \\
1.7\end{array}$ & $114 \pm 3.8$ & $\begin{array}{l}184.2 \pm \\
8.04\end{array}$ \\
\hline $\begin{array}{l}\text { Arginine } \\
\text { uptake }\end{array}$ & $\begin{array}{l}\text { nmol } \\
\left(10^{6}\right. \\
\text { cells })^{-1} \mathrm{~h}^{-} \\
1\end{array}$ & $6 \pm 0.2$ & $37 \pm 1.0$ & $15 \pm 1.2$ & $9 \pm 0.5$ & $4 \pm 0.6$ & $\begin{array}{l}63.76 \pm \\
1.26\end{array}$ \\
\hline $\begin{array}{l}\text { Valine } \\
\text { uptake }\end{array}$ & $\begin{array}{l}\text { nmol } \\
\left(10^{6}\right. \\
\text { cells })^{-1} \mathrm{~h}^{-} \\
1\end{array}$ & $-2 \pm 1.3$ & $2 \pm 2.9$ & $17.8 \pm 2.4$ & $\begin{array}{l}7.09 \pm \\
0.5\end{array}$ & $-1 \pm 0.8$ & $\begin{array}{l}24.6 \pm \\
3.9\end{array}$ \\
\hline $\begin{array}{l}\text { Leucine } \\
\text { uptake }\end{array}$ & $\begin{array}{l}\text { nmol } \\
\left(10^{6}\right. \\
\text { cells })^{-1} \mathrm{~h}^{-} \\
1\end{array}$ & $9 \pm 0.5$ & $13 \pm 2.7$ & $28.2 \pm 2.7$ & $\begin{array}{l}17.4 \pm \\
0.7\end{array}$ & $4 \pm 0.8$ & $\begin{array}{l}36.5 \pm \\
4.1\end{array}$ \\
\hline
\end{tabular}




\begin{tabular}{|c|c|c|c|c|c|c|c|}
\hline $\begin{array}{l}\text { Isoleucine } \\
\text { uptake }\end{array}$ & $\begin{array}{l}\text { nmol } \\
\left(10^{6}\right. \\
\text { cells })^{-1} \mathrm{~h}^{-} \\
1\end{array}$ & $7.4 \pm 0.5$ & $6.0 \pm 1.9$ & $28.4 \pm 2.8$ & $\begin{array}{l}15.5 \pm \\
1.2\end{array}$ & $-0.6 \pm 0.3$ & $\begin{array}{l}33.2 \pm \\
4.1\end{array}$ \\
\hline $\begin{array}{l}\text { Lactate } \\
\text { excretion }\end{array}$ & $\begin{array}{l}\text { nmol } \\
\left(10^{6}\right. \\
\text { cells })^{-1} \mathrm{~h}^{-} \\
1\end{array}$ & $313 \pm 7$ & $1014 \pm 6$ & $1734 \pm 29$ & $\begin{array}{l}1146 \pm \\
41\end{array}$ & $762 \pm 10$ & $\begin{array}{l}993 \pm \\
7.18\end{array}$ \\
\hline $\begin{array}{l}\text { Glutamate } \\
\text { excretion }\end{array}$ & $\begin{array}{l}\text { nmol } \\
\left(10^{6}\right. \\
\text { cells })^{-1} \mathrm{~h}^{-} \\
1\end{array}$ & $13 \pm 1$ & $16 \pm 1$ & $18 \pm 1$ & $41 \pm 2$ & $53 \pm 2$ & $\begin{array}{l}43.7 \pm \\
0.51\end{array}$ \\
\hline $\begin{array}{l}\text { Alanine } \\
\text { excretion }\end{array}$ & $\begin{array}{l}\text { nmol } \\
\left(10^{6}\right. \\
\text { cells })^{-1} \mathrm{~h}^{-} \\
1\end{array}$ & $\begin{array}{l}27.0 \pm \\
0.6\end{array}$ & $\begin{array}{l}22.0 \pm \\
0.8\end{array}$ & $20.9 \pm 0.9$ & $\begin{array}{l}0.0 \pm \\
0.0\end{array}$ & $\begin{array}{l}22.8 \pm \\
0.2\end{array}$ & $\begin{array}{l}19.75 \pm \\
1.11\end{array}$ \\
\hline $\begin{array}{l}\text { Proline } \\
\text { excretion }\end{array}$ & $\begin{array}{l}\text { nmol } \\
\left(10^{6}\right. \\
\text { cells })^{-1} \mathrm{~h}^{-} \\
1\end{array}$ & $3.5 \pm 0.2$ & $4.0 \pm 0.2$ & $3.1 \pm 0.3$ & $\begin{array}{l}12.1 \pm \\
0.1\end{array}$ & $4.4 \pm 0.1$ & $\begin{array}{l}11.83 \pm \\
0.286\end{array}$ \\
\hline $\begin{array}{l}\text { Ornithine } \\
\text { excretion }\end{array}$ & $\begin{array}{l}\text { nmol } \\
\left(10^{6}\right. \\
\text { cells })^{-1} \mathrm{~h}^{-} \\
1\end{array}$ & $2.9 \pm 0.1$ & $\begin{array}{l}43.0 \pm \\
1.4\end{array}$ & $4.0 \pm 1.2$ & $\begin{array}{l}4.69 \pm \\
0.1\end{array}$ & $\begin{array}{l}23.4 \pm \\
0.4\end{array}$ & $\begin{array}{l}59.7 \pm \\
1.5\end{array}$ \\
\hline
\end{tabular}


Table S2 Results of ${ }^{13} \mathrm{C}$-MFA of 12 cell lines

\begin{tabular}{|c|c|c|c|c|c|c|c|c|c|c|c|c|}
\hline & $\begin{array}{l}\mathrm{Ca} \\
\mathrm{ki}- \\
1\end{array}$ & $\begin{array}{l}\text { DL } \\
\text { D1 }\end{array}$ & $\begin{array}{l}\mathrm{HC} \\
\mathrm{T} 1 \\
16\end{array}$ & $\begin{array}{l}\mathrm{He} \\
\mathrm{pG} \\
2\end{array}$ & $\begin{array}{l}\text { HT } \\
- \\
108 \\
0\end{array}$ & $\begin{array}{l}\mathrm{Hu} \\
\mathrm{h}-1\end{array}$ & $\begin{array}{l}\mathrm{LS} \\
174 \\
\mathrm{~T}\end{array}$ & $\begin{array}{l}\text { MC } \\
\text { F7 }\end{array}$ & $\begin{array}{l}\mathrm{Mi} \\
\mathrm{aPa} \\
\mathrm{Ca} \\
2\end{array}$ & $\begin{array}{l}\text { Pan } \\
\text { c1 }\end{array}$ & $\begin{array}{l}\mathrm{Wi} \\
\mathrm{Dr}\end{array}$ & $\begin{array}{l}\text { YK } \\
\text { G1 }\end{array}$ \\
\hline \multicolumn{13}{|c|}{ Fitting results $\left(\chi^{2}\right.$ test $)$} \\
\hline RSS & $\begin{array}{l}22 . \\
3\end{array}$ & $\begin{array}{l}11 . \\
4\end{array}$ & $\begin{array}{l}33 . \\
8\end{array}$ & 3.5 & $\begin{array}{l}35 . \\
5\end{array}$ & $\begin{array}{l}16 . \\
3\end{array}$ & $\begin{array}{l}16 . \\
4\end{array}$ & $\begin{array}{l}46 . \\
2\end{array}$ & $\begin{array}{l}23 . \\
8\end{array}$ & $\begin{array}{l}33 . \\
6\end{array}$ & $\begin{array}{l}14 . \\
6\end{array}$ & $\begin{array}{l}20 . \\
3\end{array}$ \\
\hline Threshold & $\begin{array}{l}71 . \\
0\end{array}$ & $\begin{array}{l}66 . \\
3\end{array}$ & $\begin{array}{l}62 . \\
8\end{array}$ & $\begin{array}{l}33 . \\
9\end{array}$ & $\begin{array}{l}52 . \\
2\end{array}$ & $\begin{array}{l}51 . \\
0\end{array}$ & $\begin{array}{l}62 . \\
8\end{array}$ & $\begin{array}{l}51 . \\
7\end{array}$ & $\begin{array}{l}59 . \\
3\end{array}$ & $\begin{array}{l}55 . \\
8\end{array}$ & $\begin{array}{l}51 . \\
0\end{array}$ & $\begin{array}{l}41 . \\
3\end{array}$ \\
\hline p_value & $\begin{array}{l}0.9 \\
9 \\
\end{array}$ & $\begin{array}{l}0.9 \\
9 \\
\end{array}$ & $\begin{array}{l}0.9 \\
0\end{array}$ & $\begin{array}{l}0.9 \\
9 \\
\end{array}$ & $\begin{array}{l}0.5 \\
4 \\
\end{array}$ & $\begin{array}{l}0.9 \\
9 \\
\end{array}$ & $\begin{array}{l}0.9 \\
9 \\
\end{array}$ & $\begin{array}{l}0.1 \\
2\end{array}$ & $\begin{array}{l}0.9 \\
9 \\
\end{array}$ & $\begin{array}{l}0.7 \\
5 \\
\end{array}$ & $\begin{array}{l}0.9 \\
9 \\
\end{array}$ & $\begin{array}{l}0.8 \\
5 \\
\end{array}$ \\
\hline \multicolumn{13}{|c|}{ Metabolic flux $\left(\mathrm{nmol}\left(10^{6} \text { cells }\right)^{-1} \mathrm{~h}^{-1}\right)$} \\
\hline $\begin{array}{l}\text { r1_Glc_up } \\
\text { take }\end{array}$ & $\begin{array}{l}103 \\
8\end{array}$ & 729 & 417 & 713 & 761 & 342 & 219 & 565 & 878 & 567 & 445 & 493 \\
\hline r2_PGI_f & 281 & 650 & 147 & 314 & 488 & 226 & 113 & 501 & 415 & 214 & 435 & 167 \\
\hline $\mathrm{w}$ & 4 & 9 & 3 & 5 & 8 & 5 & 8 & 4 & 8 & 4 & 5 & 1 \\
\hline r3_PGI_rv & $\begin{array}{l}182 \\
0\end{array}$ & $\begin{array}{l}582 \\
9\end{array}$ & $\begin{array}{l}108 \\
3\end{array}$ & $\begin{array}{l}253 \\
1\end{array}$ & $\begin{array}{l}420 \\
6\end{array}$ & $\begin{array}{l}193 \\
7\end{array}$ & 954 & $\begin{array}{l}448 \\
9\end{array}$ & $\begin{array}{l}331 \\
4\end{array}$ & $\begin{array}{l}161 \\
4\end{array}$ & $\begin{array}{l}398 \\
6\end{array}$ & $\begin{array}{l}120 \\
0\end{array}$ \\
\hline r4_PFK & $\begin{array}{l}106 \\
0\end{array}$ & 706 & 403 & 675 & 731 & 335 & 202 & 546 & 860 & 552 & 416 & 482 \\
\hline r5_FBA_f & 238 & 607 & 205 & 155 & 304 & 524 & 145 & 417 & 147 & 577 & 977 & 141 \\
\hline $\mathrm{w}$ & 1 & 8 & 0 & 0 & 3 & & 2 & 8 & 8 & & & 1 \\
\hline r6_FBA_r & 132 & 537 & 164 & 875 & 231 & 190 & 125 & 363 & 617 & 24 & 562 & 929 \\
\hline $\mathrm{v}$ & 1 & 2 & 7 & & 2 & & 0 & 2 & & & & \\
\hline r7_TPI_fw & 306 & 609 & 400 & 523 & 349 & 258 & 208 & 216 & 867 & 226 & 425 & 312 \\
\hline & 7 & 2 & 2 & 8 & 1 & 4 & 0 & 4 & 2 & 6 & 4 & 1 \\
\hline r8_TPI_rv & 200 & 538 & 360 & 456 & 276 & 225 & 188 & 162 & 781 & 171 & 384 & 264 \\
\hline & 8 & 8 & 0 & 4 & 1 & 1 & 0 & 0 & 3 & 5 & 0 & 0 \\
\hline r9_GAPD & 293 & 291 & 139 & 181 & 252 & 237 & 189 & 462 & 940 & 162 & 193 & 276 \\
\hline H_fw & 6 & 5 & 3 & 8 & 6 & 8 & 1 & 0 & 7 & 4 & 4 & 1 \\
\hline r10_GAP & 784 & 149 & 582 & 438 & 104 & 170 & 147 & 352 & 768 & 509 & 108 & 179 \\
\hline DH_rv & & 3 & & & 2 & 7 & 9 & 0 & 0 & & 1 & 2 \\
\hline r11_PEPH & 300 & 646 & 140 & 152 & 232 & 903 & 182 & 484 & 281 & 196 & 366 & 340 \\
\hline _fw & 7 & 9 & 1 & 3 & 3 & & 6 & 6 & 4 & 6 & 6 & 1 \\
\hline r12_PEPH & 861 & 505 & 597 & 152 & 844 & 236 & 142 & 375 & 109 & 854 & 282 & 243 \\
\hline _rv & & 7 & & & & & 4 & 6 & 7 & & 1 & 8 \\
\hline r13_PK & $\begin{array}{l}214 \\
6\end{array}$ & $\begin{array}{l}141 \\
1\end{array}$ & 804 & $\begin{array}{l}137 \\
2\end{array}$ & $\begin{array}{l}147 \\
8\end{array}$ & 667 & 403 & $\begin{array}{l}109 \\
1\end{array}$ & $\begin{array}{l}171 \\
7\end{array}$ & $\begin{array}{l}111 \\
2\end{array}$ & 846 & 963 \\
\hline r16_PDH & 121 & 93 & 65 & 31 & 56 & 73 & 80 & 66 & 50 & 62 & 67 & 56 \\
\hline r17_CS & 121 & 93 & 65 & 31 & 56 & 73 & 80 & 66 & 50 & 62 & 67 & 56 \\
\hline $\begin{array}{l}\text { r18_IDH_ } \\
\text { fw }\end{array}$ & 145 & 59 & 42 & 15 & 34 & 81 & 73 & 74 & 33 & 72 & 53 & 42 \\
\hline $\begin{array}{l}\text { r19_IDH_ } \\
\text { rv }\end{array}$ & 48 & 12 & 9 & 18 & 4 & 27 & 30 & 48 & 25 & 24 & 16 & 11 \\
\hline $\begin{array}{l}\text { r20_AKG } \\
\text { DH }\end{array}$ & 238 & 97 & 94 & 37 & 140 & 176 & 81 & 48 & 127 & 158 & 58 & 149 \\
\hline
\end{tabular}




\begin{tabular}{|c|c|c|c|c|c|c|c|c|c|c|c|c|}
\hline $\begin{array}{l}\text { r21_SDH_ } \\
\mathrm{fw}\end{array}$ & 437 & $\begin{array}{l}409 \\
5\end{array}$ & 229 & $\begin{array}{l}722 \\
6\end{array}$ & 967 & $\begin{array}{l}325 \\
5\end{array}$ & 664 & 80 & $\begin{array}{l}644 \\
4\end{array}$ & 191 & $\begin{array}{l}154 \\
7\end{array}$ & 922 \\
\hline $\begin{array}{l}\text { r22_SDH_ } \\
\text { rv }\end{array}$ & 199 & $\begin{array}{l}399 \\
8\end{array}$ & 135 & $\begin{array}{l}718 \\
9\end{array}$ & 827 & $\begin{array}{l}307 \\
9\end{array}$ & 584 & 33 & $\begin{array}{l}631 \\
8\end{array}$ & 33 & $\begin{array}{l}148 \\
8\end{array}$ & 773 \\
\hline r23_FH_f & 600 & 620 & 337 & 157 & 140 & 117 & 871 & 326 & 101 & 420 & 479 & 475 \\
\hline W & 8 & 5 & & 5 & & 1 & & 6 & 39 & 1 & 1 & \\
\hline 24_FH_r & 576 & 610 & 243 & 153 & 0 & 995 & 790 & 321 & 100 & 404 & 473 & 326 \\
\hline $\mathrm{V}$ & 9 & 7 & & 8 & & & & 8 & 12 & 3 & 3 & \\
\hline $\begin{array}{l}\text { r25_MDH } \\
\text { _fw }\end{array}$ & 225 & 197 & 85 & 90 & 66 & $\begin{array}{l}165 \\
2\end{array}$ & $\begin{array}{l}221 \\
6\end{array}$ & 106 & 102 & 62 & 512 & 181 \\
\hline $\begin{array}{l}\text { r26_MDH } \\
\text { _rv }\end{array}$ & 116 & 111 & 28 & 78 & 15 & $\begin{array}{l}168 \\
0\end{array}$ & $\begin{array}{l}214 \\
2\end{array}$ & 62 & 63 & 0 & 446 & 138 \\
\hline 27_PC & 13 & 6 & 8 & 19 & 5 & 100 & 7 & 22 & 11 & 0 & 1 & 13 \\
\hline r28_MAE & 147 & 44 & 61 & 49 & 108 & 217 & 34 & 33 & 118 & 106 & 13 & 125 \\
\hline $\begin{array}{l}\text { r29_G6PD } \\
\mathrm{H}\end{array}$ & 102 & 43 & 23 & 94 & 75 & 11 & 31 & 36 & 30 & 35 & 73 & 10 \\
\hline $\begin{array}{l}\text { r30_6PGD } \\
\mathrm{H}\end{array}$ & 102 & 43 & 23 & 94 & 75 & 11 & 31 & 36 & 30 & 35 & 73 & 19 \\
\hline r31_RPI_f & 605 & 588 & 251 & 525 & 370 & 297 & 106 & 453 & 103 & 438 & 236 & 200 \\
\hline W & 8 & 0 & 9 & 4 & 5 & 7 & 0 & 2 & 10 & 9 & 7 & 1 \\
\hline r32_RPI_r & 602 & 586 & 250 & 522 & 367 & 297 & 104 & 451 & 102 & 437 & 234 & 199 \\
\hline$v$ & 2 & 3 & 9 & 1 & 9 & 2 & 7 & 8 & 97 & 6 & 1 & 3 \\
\hline r33_RPE_ & 577 & 435 & 284 & 64 & 463 & 351 & 222 & 493 & 875 & 481 & 199 & 367 \\
\hline fw & 8 & 1 & 9 & & 4 & 5 & 0 & 1 & 4 & 1 & 2 & 3 \\
\hline r34_RPE_ & 571 & 432 & 283 & 3 & 458 & 350 & 220 & 491 & 873 & 478 & 194 & 366 \\
\hline $\mathrm{rv}$ & 2 & 5 & 6 & & 5 & 9 & 2 & 0 & 7 & 8 & 5 & 2 \\
\hline $\begin{array}{l}\text { r35_TKL1 } \\
\text { _fw }\end{array}$ & 346 & 44 & $\begin{array}{l}218 \\
8\end{array}$ & $\begin{array}{l}674 \\
2\end{array}$ & 439 & 10 & 21 & 42 & 33 & 85 & $\begin{array}{l}368 \\
2\end{array}$ & 27 \\
\hline $\begin{array}{l}\text { r36_TKL1 } \\
\text { rv }\end{array}$ & 313 & 31 & $\begin{array}{l}218 \\
1\end{array}$ & $\begin{array}{l}671 \\
2\end{array}$ & 415 & 7 & 12 & 32 & 25 & 73 & $\begin{array}{l}365 \\
9\end{array}$ & 21 \\
\hline $\begin{array}{l}\text { r37_TAL1 } \\
\text { fw }\end{array}$ & 100 & 81 & 32 & $\begin{array}{l}753 \\
3\end{array}$ & 94 & 22 & $\begin{array}{l}133 \\
6\end{array}$ & $\begin{array}{l}507 \\
0\end{array}$ & $\begin{array}{l}465 \\
3\end{array}$ & 50 & 37 & 59 \\
\hline $\begin{array}{l}\text { r38_TAL1 } \\
\text { rv }\end{array}$ & 67 & 68 & 25 & $\begin{array}{l}750 \\
3\end{array}$ & 70 & 19 & $\begin{array}{l}132 \\
7\end{array}$ & $\begin{array}{l}505 \\
9\end{array}$ & $\begin{array}{l}464 \\
4\end{array}$ & 39 & 14 & 53 \\
\hline $\begin{array}{l}\text { r39_TKL2 } \\
\text { fw }\end{array}$ & 33 & 13 & 7 & $\begin{array}{l}543 \\
5\end{array}$ & 24 & 3 & 9 & 11 & 9 & 11 & 23 & 5 \\
\hline $\begin{array}{l}\text { r40_TKL2 } \\
\text { rrv }\end{array}$ & 0 & 0 & 0 & $\begin{array}{l}540 \\
5\end{array}$ & 0 & 0 & 0 & 0 & 0 & 0 & 0 & 0 \\
\hline r41_LDH & $\begin{array}{l}215 \\
4\end{array}$ & $\begin{array}{l}132 \\
1\end{array}$ & 775 & $\begin{array}{l}128 \\
2\end{array}$ & $\begin{array}{l}151 \\
1\end{array}$ & 707 & 313 & $\begin{array}{l}100 \\
3\end{array}$ & $\begin{array}{l}174 \\
3\end{array}$ & $\begin{array}{l}115 \\
3\end{array}$ & 761 & 992 \\
\hline $\begin{array}{l}\text { r42_Lac_e } \\
\text { xcretion }\end{array}$ & $\begin{array}{l}215 \\
4\end{array}$ & $\begin{array}{l}132 \\
1\end{array}$ & 775 & $\begin{array}{l}128 \\
2\end{array}$ & $\begin{array}{l}151 \\
1\end{array}$ & 707 & 313 & $\begin{array}{l}100 \\
3\end{array}$ & $\begin{array}{l}174 \\
3\end{array}$ & $\begin{array}{l}115 \\
3\end{array}$ & 761 & 992 \\
\hline $\begin{array}{l}\text { r46_Gln_u } \\
\text { ptake }\end{array}$ & 329 & 84 & 102 & 251 & 277 & 165 & 72 & 71 & 154 & 166 & 114 & 185 \\
\hline r47_GLC & 325 & 78 & 98 & 247 & 273 & 163 & 67 & 05 & 148 & 164 & 110 & 182 \\
\hline $\begin{array}{l}\text { r49_GDH } \\
\text { fw }\end{array}$ & $\begin{array}{l}605 \\
9\end{array}$ & 254 & 382 & 39 & 604 & 703 & 222 & 445 & $\begin{array}{l}103 \\
1\end{array}$ & 538 & 481 & 119 \\
\hline
\end{tabular}


r50_GDH $\quad 591 \quad 204 \quad 321 \quad 0 \quad 494 \quad 580 \quad 185 \quad 422 \quad 912 \quad 428 \quad 460 \quad 0$ $\begin{array}{lllllllllllll}\text { rrv } & 8 & & & & & & & & & & & \end{array}$ xcretion

$\begin{array}{lllllllllllll}\text { r52_Pro } & 38 & 15 & 6 & 25 & 16 & 8 & 8 & 9 & 9 & 14 & 8 & 15\end{array}$

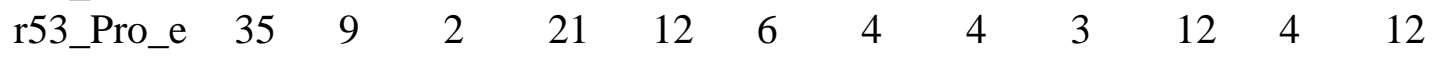
xcretion

$\begin{array}{lllllllllllll}\text { r54_Asp } & 7 & 13 & 9 & 10 & 8 & 5 & 11 & 12 & 12 & 4 & 8 & 7\end{array}$

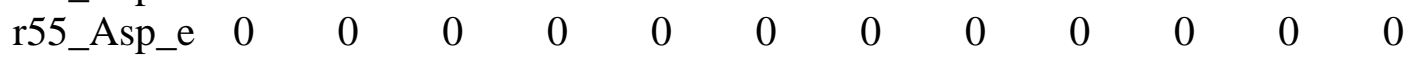
xcretion

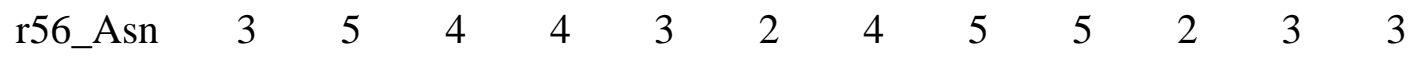

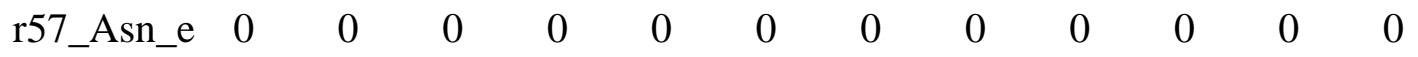
xcretion

$\begin{array}{lllllllllllll}\text { r58_GPT } & 6 & 34 & 17 & 88 & 14 & 4 & 36 & 32 & 31 & 4 & 30 & 26\end{array}$

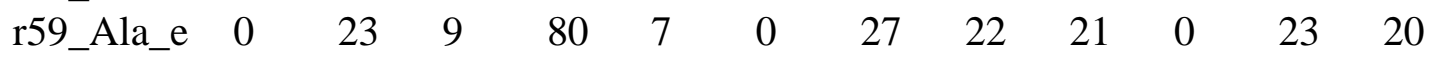

xcretion

$\begin{array}{lllllllllllll}\text { r71_Leu_u } & 6 & 11 & 7 & 8 & 0 & 4 & 8 & 9 & 10 & 3 & 7 & 6\end{array}$ ptake

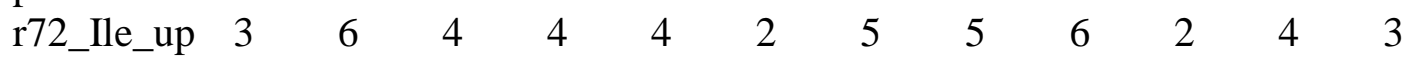
take $\begin{array}{lllllllllllll}\text { r75_Val_u } & 4 & 8 & 5 & 6 & 4 & 3 & 6 & 7 & 7 & 2 & 5 & 4\end{array}$ ptake

$\begin{array}{lllllllllllll}\text { r77_Arg_u } & 22 & 25 & 26 & 83 & 57 & 22 & 6 & 37 & 15 & 10 & 5 & 64\end{array}$ ptake

$\begin{array}{lllllllllllll}\text { r78_Arg_d } & 18 & 18 & 21 & 78 & 53 & 19 & 0 & 31 & 8 & 7 & 0 & 60\end{array}$ egradation

r79_Orn_e $\quad \begin{array}{llllllllllll}18 & 22 & 24 & 120 & 63 & 6 & 3 & 42 & 4 & 5 & 23 & 60\end{array}$ Xcretion

$\begin{array}{lllllllllllll}\text { r82_ACY } & 24 & 46 & 32 & 33 & 26 & 19 & 37 & 41 & 43 & 15 & 30 & 26\end{array}$ $\begin{array}{lllllllllllll}\mathrm{L} & & & & & & & & & & & & \end{array}$ A BIO

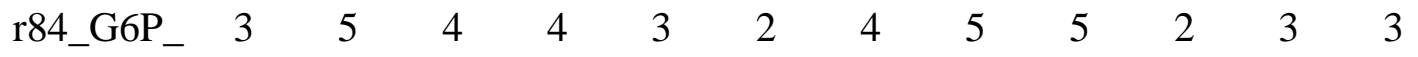
$\mathrm{BIO}$ $\begin{array}{lllllllllllll}\text { r85_R5P_ } & 2 & 4 & 3 & 3 & 2 & 2 & 3 & 4 & 4 & 1 & 3 & 2\end{array}$ $\mathrm{BIO}$ $\begin{array}{lllllllllllll}\text { r86_DHA } & 1 & 2 & 2 & 2 & 1 & 1 & 2 & 2 & 2 & 1 & 1 & 1\end{array}$ P_BIO $\begin{array}{lllllllllllll}\text { r87_Ser_B } & 6 & 11 & 8 & 8 & 6 & 4 & 9 & 10 & 10 & 4 & 7 & 6\end{array}$ IO

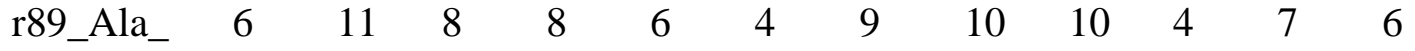
BIO $\begin{array}{lllllllllllll}\text { r90_Asp_ } & 4 & 8 & 5 & 6 & 4 & 3 & 6 & 7 & 7 & 2 & 5 & 4\end{array}$ BIO

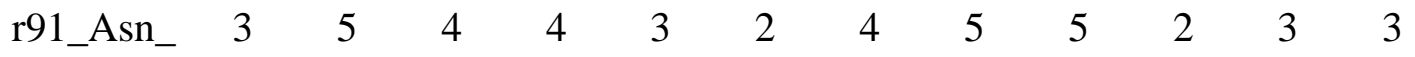
BIO $\begin{array}{lllllllllllll}\text { r92_Glu_ } & 4 & 7 & 5 & 5 & 4 & 3 & 6 & 6 & 7 & 2 & 5 & 4\end{array}$ BIO 


\begin{tabular}{|c|c|c|c|c|c|c|c|c|c|c|c|}
\hline $\begin{array}{l}\text { r93_Gln_ } \\
\text { BIO }\end{array}$ & 3 & 6 & 4 & 4 & 3 & 2 & 5 & 5 & 6 & 2 & 4 \\
\hline $\begin{array}{l}\text { r94_Pro_B } \\
\text { IO }\end{array}$ & 3 & 6 & 4 & 4 & 3 & 2 & 5 & 5 & 5 & 2 & 4 \\
\hline $\begin{array}{l}\text { r95_Arg_A } \\
\text { BIO }\end{array}$ & 4 & 7 & 5 & 5 & 4 & 3 & 6 & 6 & 7 & 2 & 5 \\
\hline $\begin{array}{l}\text { r96_Leu_ } \\
\text { BIO }\end{array}$ & 6 & 11 & 7 & 8 & 0 & 4 & 8 & 9 & 10 & 3 & 7 \\
\hline $\begin{array}{l}\text { r97_Ile_BI } \\
\mathrm{O}\end{array}$ & 3 & 6 & 4 & 4 & 4 & 2 & 5 & 5 & 6 & 2 & 4 \\
\hline r98_Val_ & 4 & 8 & 5 & 6 & 4 & 3 & 6 & 7 & 7 & 2 & 5 \\
\hline
\end{tabular}

$\mathrm{BIO}$

r100_CO2 $6066663 \quad 361 \quad 754 \quad 603 \quad 397 \quad 222 \quad 507 \quad 103 \quad 556 \quad 481 \quad 366$

$\begin{array}{lllllllllll}\text { _in } & 0 & 1 & 0 & 6 & 9 & 0 & 0 & 0 & 10 & 0\end{array}$

r101_CO2 $536 \quad 631 \quad 334 \quad 735 \quad 563 \quad 353 \quad 195 \quad 488 \quad 998 \quad 147 \quad 456 \quad 0$

$\begin{array}{llllllllllll}\text { _ex } & 7 & 3 & 3 & 6 & 5 & 9 & 8 & 4 & 9 & 2\end{array}$

$\begin{array}{lllllllllllll}\text { r104_MA } & 69 & 675 & 310 & 71 & 349 & 74 & 219 & 151 & 891 & 30 & 478 & 363\end{array}$

$\begin{array}{lllllllll}\text { L_transpor } & 8 & 3 & 5 & 0 & 2 & 2 & 9 & 4\end{array}$

$\mathrm{t} \_\mathrm{fw}$

$\begin{array}{lllllllllllll}\text { r105_MA } & 86 & 679 & 312 & 95 & 351 & 87 & 221 & 154 & 894 & 41 & 481 & 365\end{array}$

$\begin{array}{llllllllll}\text { L_transpor } & 1 & 6 & 4 & 6 & 1 & 2 & 0 & 3\end{array}$

t_rv

$\begin{array}{lllllllllllll}\text { r106_MD } & 504 & 81 & 599 & 580 & 7 & 386 & 219 & 504 & 942 & 66 & 188 & 329\end{array}$

$\begin{array}{llllllllll}\text { H_cyt_fw } & 1 & 4 & 1 & 3 & 1 & 1 & 0 & 7\end{array}$

$\begin{array}{lllllllllllll}\text { r107_MD } & 505 & 114 & 622 & 582 & 26 & 387 & 221 & 507 & 945 & 77 & 190 & 331\end{array}$

$\begin{array}{llllllllll}\text { H_cyt } & 8 & 8 & 4 & 9 & 0 & 1 & 1 & 6\end{array}$

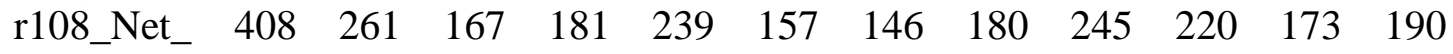

$\begin{array}{llllllllllllll}\text { ATP_prod } & 6 & 8 & 4 & 7 & 6 & 1 & 0 & 6 & 5 & 5 & 1 & 8\end{array}$

uction

$\begin{array}{lllllllllllll}\text { r109_OXP } & 688 & 451 & 317 & 174 & 316 & 333 & 397 & 280 & 254 & 376 & 334 & 327\end{array}$

HOS

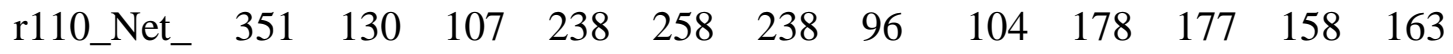

$\mathrm{NADPH}_{-}$

production

$\begin{array}{lllllllllllll}\text { PGI } & 994 & 680 & 390 & 615 & 683 & 329 & 184 & 525 & 843 & 530 & 369 & 471 \\ \text { FBA } & 106 & 706 & 403 & 675 & 731 & 335 & 202 & 546 & 860 & 552 & 416 & 482 \\ & 0 & & & & & & & & & & & \\ \text { TPI } & 105 & 704 & 402 & 674 & 730 & 334 & 200 & 544 & 858 & 552 & 414 & 481 \\ & 9 & & & & & & & & & & & \\ \text { GAPDH } & 215 & 142 & 812 & 138 & 148 & 671 & 412 & 110 & 172 & 111 & 853 & 969 \\ & 2 & 3 & & 0 & 5 & & & 1 & 7 & 5 & & \\ \text { PEPH } & 214 & 141 & 804 & 137 & 147 & 667 & 403 & 109 & 171 & 111 & 846 & 963 \\ & 6 & 1 & & 2 & 8 & & & 1 & 7 & 2 & & \\ \text { IDH } & 97 & 47 & 32 & -2 & 30 & 54 & 43 & 25 & 7 & 47 & 37 & 30 \\ \text { SDH } & 238 & 97 & 94 & 37 & 140 & 176 & 81 & 48 & 127 & 158 & 58 & 149 \\ \text { MDH } & 108 & 87 & 56 & 12 & 51 & -27 & 73 & 44 & 39 & 62 & 66 & 43 \\ \text { RPI } & 36 & 17 & 10 & 34 & 27 & 5 & 13 & 14 & 13 & 13 & 26 & 8 \\ \text { RBE } & 66 & 26 & 13 & 61 & 48 & 6 & 18 & 21 & 17 & 23 & 46 & 11 \\ & & & & & & 31 & & & & & & \end{array}$


bioRxiv preprint doi: https://doi.org/10.1101/2021.11.16.468557; this version posted November 19,2021 . The copyright holder for this preprint (which was not certified by peer review) is the author/funder, who has granted bioRxiv a license to display the preprint in perpetuity. It is made available under aCC-BY-ND 4.0 International license.

\begin{tabular}{lllllllllllll} 
TKT1 & 33 & 13 & 7 & 30 & 24 & 3 & 9 & 11 & 9 & 11 & 23 & 5 \\
TAL & 33 & 13 & 7 & 30 & 24 & 3 & 9 & 11 & 9 & 11 & 23 & 5 \\
TKT2 & 33 & 13 & 7 & 30 & 24 & 3 & 9 & 11 & 9 & 11 & 23 & 5 \\
FH & 238 & 97 & 94 & 37 & 140 & 176 & 81 & 48 & 127 & 158 & 58 & 149 \\
MDHcyt & -17 & -33 & -23 & -24 & -19 & -13 & -26 & -29 & -31 & -11 & -21 & -19 \\
\hline GDH & 141 & 51 & 62 & 39 & 110 & 122 & 37 & 22 & 119 & 110 & 21 & 119 \\
\hline
\end{tabular}


Table S3 Constraints of medium components for flux balance analysis.

\section{Constraint}

Uptake:

Forbidden,

Excretion:

Allowed

Uptake:

Allowed,

Excretion:

Allowed

Fixed at

measured value

Uptake:

Forbidden,

Excretion:

Forbidden

\section{Medium components}

M_nh4_b, M_co2tot_b, M_lac_L_b, M_urea_b, M_gudac_b,

M_biomass_b

M_glc_D_b, M_gln_L_b, M_ile_L_b, M_leu_L_b, M_lys_L_b, M_phe_L_b, M_thr_L_b, M_trp_L_b, M_tyr_L_b, M_val_L_b, M_his_L_b, M_met_L_b, M_chol_b, M_h_b, M_h2o_b, M_pi_b, M_o2_b, M_biomass_other_c, ent_ex_ M_arg_L_b, M_orn_b, M_glu_L_b, M_pro_L_b, M_ala_L_b, M_asn_L_b, M_asp_L_b

M_13_cis_oretn_b, M_13_cis_retn_b, M_Asn_X_Ser_Thr_b, M_avite1_b, M_avite2_b, M_bvite_b, M_core5_b, M_core7_b, M_core8_b, M_datp_b, M_datp_b, M_dctp_b, M_dctp_b, M_dem2emgacpail_prot_hs_b, M_dgpi_prot_hs_b, M_dgtp_b, M_dgtp_b, M_dttp_b, M_dttp_b, M_ethamp_b, M_gncore2_b, M_gpi_sig_b, M_hretn_b, M_mem2emgacpail_prot_hs_b, M_n5m2masn_b, M_oretn_b, M_Ser_Thr_b,

M_Ser_Gly_Ala_X_Gly_b, M_sprm_b, M_T_antigen_b, M_yvite_b, M_citr_L_b, M_pre_prot_b, M_c81coa_b, M_dd2coa_b, M_decdicoa_b, M_octdececoa_b, M_tetdece1coa_b, M_1a25dhvitd3_b, M_4abut_b, M_5HPET_b, M_taur_b, M_pe_hs_b, M_pmtcoa_b, M_5HPET_b, M_4hpro_LT_b, M_Lcystin_b, M_anth_b, M_btn_b, M_fol_b, M_ncam_b, M_pnto_R_b, M_10fthf_b, M_11_cis_retfa_b, M_13_cis_retnglc_b, M_1glyc_hs_b, M_1mncam_b, M_2425dhvitd2_b, M_2425dhvitd3_b, M_24nph_b, M_25hvitd2_b, M_25hvitd3_b, M_2hb_b, M_2mcit_b, M_34dhoxpeg_b, M_34dhphe_b, M_35cgmp_b, M_3aib_b, M_3aib_D_b, M_3mlda_b, M_4abut_b, M_4hdebrisoquine_b, M_4hphac_b, M_4mptnl_b, M_4mtolbutamide_b, M_4nph_b, M_4nphsf_b, M_4pyrdx_b, M_5adtststerone_b, M_5adtststeroneglc_b, M_5fthf_b, M_5homeprazole_b, M_5htrp_b, M_5mthf_b, M_6htststerone_b, M_9_cis_retfa_b, M_abt_b, M_ac_b, M_acac_b, M_acald_b, M_acetone_b, M_acgalfucgalacgalfuc12gal14acglcgalgluside_hs_b, M_acgalfucgalacgalfucgalacglcgal14acglcgalgluside_hs_b, M_acgam_b, M_ach_b, M_ade_b, M_adn_b, M_adp_b, M_adprbp_b, M_adprib_b, M_adrn_b, M_adrnl_b, M_aflatoxin_b, M_ahandrostanglc_b, M_ak2lgchol_hs_b, M_akg_b, M_ala_B_b, M_ala_D_b, M_aldstrn_b, M_amp_b, M_andrstrn_b, M_andrstrnglc_b, M_antipyrene_b, M_apnnox_b, M_appnn_b, M_aprgstrn_b, M_aqcobal_b, M_arab_L_b, M_arach_b, M_arachd_b, M_ascb_L_b, M_asp_D_b, M_atp_b, M_avite1_b, M_avite2_b, M_bhb_b, M_bildglcur_b, M_bilglcur_b, M_bilirub_b, M_biocyt_b, M_btn_b, M_but_b, 
M_bvite_b, M_bz_b, M_ca2_b, M_camp_b, M_caro_b,

M_carveol_b, M_cgly_b, M_cholate_b, M_chsterol_b, M_chtn_b,

M_cit_b, M_clpnd_b, M_cmp_b, M_co_b, M_coumarin_b,

M_creat_b, M_crmp_hs_b, M_crn_b, M_crtsl_b, M_crtstrn_b,

M_crvnc_b, M_csn_b, M_cyan_b, M_cys_L_b, M_cytd_b,

M_dad_2_b, M_dag_hs_b, M_dcsptn1_b, M_dcyt_b,

M_debrisoquine_b, M_dgchol_b, M_dgsn_b, M_dhdascb_b,

M_dheas_b, M_dhf_b, M_digalsgalside_hs_b, M_din_b,

M_dlnlcg_b, M_dmantipyrine_b, M_dmhptcrn_b, M_dopa_b,

M_dopasf_b, M_drib_b, M_duri_b, M_eaflatoxin_b,

M_ebastine_b, M_ebastineoh_b, M_eicostet_b, M_elaid_b,

M_estradiol_b, M_estradiolglc_b, M_estriolglc_b,

M_estroneglc_b, M_estrones_b, M_etoh_b, M_fe2_b, M_fe3_b,

M_fol_b, M_for_b, M_fru_b,

M_fuc13galacglcgal14acglcgalgluside_hs_b,

M_fuc14galacglcgalgluside_hs_b,

M_fucacgalfucgalacglcgalgluside_hs_b,

M_fucacngal14acglcgalgluside_hs_b,

M_fucfuc12gal14acglcgalgluside_hs_b,

M_fucfuc132galacglcgal14acglcgalgluside_hs_b,

M_fucfucfucgalacglc13galacglcgal14acglcgalgluside_hs_b,

M_fucfucfucgalacglcgal14acglcgalgluside_hs_b,

M_fucfucgalacglcgalgluside_hs_b,

M_fucgal14acglcgalgluside_hs_b,

M_fucgalfucgalacglcgalgluside_hs_b, M_fucgalgbside_hs_b,

M_fuc_L_b, M_gal_b, M_galacglcgalgbside_hs_b,

M_galfuc12gal14acglcgalgluside_hs_b,

M_galfucgalacglcgal14acglcgalgluside_hs_b,

M_galgalfucfucgalacglcgalacglcgal14acglcgalgluside_hs_b,

M_galgalgalthcrm_hs_b, M_gam_b, M_gbside_hs_b,

M_gchola_b, M_gdp_b, M_gluala_b, M_gly_b, M_glyb_b,

M_glyc_b, M_glyc_S_b, M_glygn2_b, M_glygn4_b,

M_glygn5_b, M_gmp_b, M_gsn_b, M_gtla_hs_b, M_gthox_b,

M_gthrd_b, M_gtp_b, M_gua_b, M_h_b, M_h2o2_b, M_ha_b,

M_ha_pre1_b, M_hco3_b, M_hcoumarin_b, M_hdca_b,

M_hdcea_b, M_hestratriol_b, M_hexc_b, M_hista_b,

M_hom_L_b, M_hpdca_b, M_htaxol_b, M_hxan_b, M_i_b,

M_idp_b, M_imp_b, M_inost_b, M_ins_b, M_lac_D_b, M_lcts_b,

M_Lcystin_b, M_leuktrA4_b, M_leuktrB4_b, M_leuktrC4_b,

M_leuktrD4_b, M_leuktrE4_b, M_leuktrF4_b, M_lgnc_b,

M_limnen_b, M_lipoate_b, M_lnlc_b, M_lnlnca_b, M_lnlncg_b,

M_lpchol_hs_b, M_mag_hs_b, M_malt_b, M_malttr_b,

M_man_b, M_meoh_b, M_mepi_b, M_mthgxl_b,

M_n2m2nmasn_b, M_nac_b, M_nad_b, M_nadp_b, M_ncam_b,

M_no_b, M_npthl_b, M_nrpphr_b, M_nrpphrsf_b, M_nrvnc_b,

M_o2s_b, M_ocdca_b, M_ocdcea_b, M_octa_b,

M_omeprazole_b, M_onpthl_b, M_oxa_b, M_paf_hs_b,

M_pchol_hs_b, M_pe_hs_b, M_peplys_b, M_perillyl_b, 
M_pglyc_hs_b, M_pheacgln_b, M_pheme_b, M_phyQ_b,

M_phyt_b, M_pnto_R_b, M_ppa_b, M_prgstrn_b, M_pro_D_b,

M_prostgd2_b, M_prostge1_b, M_prostge2_b, M_prostgf2_b,

M_ps_hs_b, M_ptdca_b, M_pydam_b, M_pydx_b, M_pydxn_b,

M_pyr_b, M_rbt_b, M_retfa_b, M_retinol_b, M_retinol_9_cis_b,

M_retinol_cis_11_b, M_retn_b, M_retnglc_b, M_rib_D_b,

M_ribflv_b, M_Rtotal_b, M_sarcs_b, M_sel_b, M_ser_D_b,

M_ser_L_b, M_sl_L_b, M_so4_b, M_spc_hs_b, M_sph1p_b,

M_sphs1p_b, M_srtn_b, M_strch1_b, M_strch2_b, M_strdnc_b,

M_succ_b, M_sucr_b, M_tag_hs_b, M_tagat_D_b, M_taur_b,

M_taxol_b, M_tchola_b, M_tcynt_b, M_tdchola_b, M_tethex3_b,

M_tetpent3_b, M_thf_b, M_thm_b, M_thmmp_b, M_thmtp_b,

M_thym_b, M_thymd_b, M_thyox_L_b, M_tmndnc_b,

M_tolbutamide_b, M_tre_b, M_triodthy_b, M_triodthysuf_b,

M_tststerone_b, M_tststeroneglc_b, M_tsul_b, M_ttdca_b,

M_txa2_b, M_tymsf_b, M_Tyr_ggn_b, M_udp_b, M_ump_b,

M_ura_b, M_urate_b, M_uri_b, M_utp_b, M_vacc_b, M_vitd2_b,

M_vitd3_b, M_whddca_b, M_whhdca_b, M_whtststerone_b,

M_xolest2_hs_b, M_xoltri24_b, M_xoltri25_b, M_xoltri27_b,

M_xyl_D_b, M_xylt_b, M_yvite_b, M_4abutn_b, M_acmana_b,

M_ahdt_b, M_ctp_b, M_dgmp_b, M_dgtp_b, M_dha_b,

M_dhap_b, M_dtmp_b, M_dttp_b, M_fad_b, M_fald_b,

M_g1p_b, M_HC00229_b, M_HC00250_b, M_HC01104_b,

M_HC01361_b, M_HC01440_b, M_HC01441_b,

M_HC01444_b, M_HC01446_b, M_HC01577_b,

M_HC01609_b, M_HC01610_b, M_HC01700_b,

M_HC02160_b, M_HC02161_b, M_itp_b, M_orot_b, M_prpp_b,

M_ptrc_b, M_pydx5p_b, M_spmd_b, M_udpg_b, M_no2_b,

M_so3_b, M_sprm_b, M_prostgh2_b, M_prostgi2_b, M_ppi_b,

M_cdp_b, M_dtdp_b, M_HC00955_b, M_citr_L_b,

M_HC01787_b, M_C02470_b, M_HC00822_b, M_C02528_b,

M_HC02192_b, M_CE5560_b, M_HC02195_b, M_HC02196_b,

M_HC02220_b, M_HC02154_b, M_ddca_b, M_HC02199_b,

M_HC02200_b, M_HC02201_b, M_HC02172_b,

M_HC02191_b, M_HC02194_b, M_HC02197_b,

M_HC02198_b, M_HC02187_b, M_HC02180_b,

M_wharachd_b, M_HC02202_b, M_HC02203_b,

M_HC02204_b, M_HC02205_b, M_HC02206_b,

M_HC02207_b, M_HC02208_b, M_HC02210_b,

M_HC02213_b, M_HC02214_b, M_HC02216_b,

M_HC02217_b, M_malcoa_b, M_arachcoa_b, M_coa_b,

M_CE2250_b, M_CE1940_b, M_CE2011_b, M_maltttr_b,

M_maltpt_b, M_malthx_b, M_malthp_b, M_CE2839_b,

M_CE2838_b, M_CE1950_b, M_cynt_b, M_23cump_b,

M_3ump_b, M_CE5797_b, M_CE5798_b, M_CE4633_b,

M_CE4881_b, M_glcur_b, M_udpgal_b, M_crm_hs_b,

M_galside_hs_b, M_CE0074_b, M_cdpea_b, M_12HPET_b,

M_C04849_b, M_3bcrn_b, M_3ddcrn_b, M_3deccrn_b, 
M_3hdececrn_b, M_3hexdcrn_b, M_3ivcrn_b, M_3octdec2crn_b,

M_3octdeccrn_b, M_3octdece1crn_b, M_3tdcrn_b,

M_3tetd7ecoacrn_b, M_3thexddcoacrn_b, M_3ttetddcoacrn_b,

M_c101crn_b, M_c10crn_b, M_c4crn_b, M_c51crn_b,

M_c5dc_b, M_c6crn_b, M_c81crn_b, M_c8crn_b,

M_ddece1crn_b, M_ddeccrn_b, M_decdicrn_b, M_doco13ac_b,

M_docosac_b, M_ivcrn_b, M_ttdcrn_b, M_tetdec2crn_b,

M_tetdece1crn_b, M_dca_b, M_4hpro_LT_b, M_adocbl_b,

M_alaala_b, M_bglc_b, M_carn_b, M_dchac_b, M_glgchlo_b,

M_gltcho_b, M_glygly_b, M_glyleu_b, M_glyphe_b,

M_glypro_b, M_glysar_b, M_gum_b, M_gumgchol_b,

M_gumtchol_b, M_leugly_b, M_leuleu_b, M_pectingchol_b,

M_pectintchol_b, M_progly_b, M_psyl_b, M_psylchol_b,

M_psyltchol_b, M_sbt_D_b, M_slfcys_b, M_tdechola_b,

M_cysam_b, M_dpcoa_b, M_fmn_b, M_hyptaur_b, M_oh1_b,

M_pan4p_b, M_ptth_b, M_q10_b, M_q10h2_b, M_34hpp_b,

M_3mob_b, M_3mop_b, M_4mop_b, M_5mta_b, M_5oxpro_b,

M_ahcys_b, M_aicar_b, M_anth_b, M_cbasp_b, M_mal_L_b,

M_idour_b, M_fum_b, M_xmp_b, M_dcmp_b, M_HC00342_b,

M_glyc3p_b 


\section{Table S4 Comparison of thermodynamic parameters}

\begin{tabular}{|c|c|c|c|c|c|c|}
\hline & & & & & \multicolumn{2}{|c|}{ Generation per mol ATP } \\
\hline & $\begin{array}{l}\text { Glucos } \\
\mathrm{e}\end{array}$ & $\mathrm{O}_{2}$ & $\begin{array}{l}\text { Lactic } \\
\text { acid }\end{array}$ & $\begin{array}{l}\text { Total } \\
\mathrm{CO}_{2}\end{array}$ & $\begin{array}{l}\text { Aerobic } \\
\text { glycolysis } \\
\text { (Glucose => } \\
2 \text { Lactic acid) }\end{array}$ & $\begin{array}{l}\text { OXPHOS } \\
(\text { Glucose } \\
+6 \mathrm{O}_{2}=> \\
6 \text { Total } \\
\left.\mathrm{CO}_{2}\right)\end{array}$ \\
\hline $\begin{array}{l}\text { Enthalpy } \\
\text { change } \\
\text { (heat), }-\Delta_{\mathrm{r}} H^{\circ} \\
\mathrm{kJ} \mathrm{mol}^{-1} 1 \text { ) }\end{array}$ & 1266.0 & 11.7 & 688.0 & 693.0 & 55.0 & 88.2 \\
\hline $\begin{array}{l}\text { Entropy, } S_{\mathrm{m}} \mathrm{J} \\
\mathrm{K}^{-1} \mathrm{~mol}^{-14)}\end{array}$ & 212 & 204.8 & 192 & $\begin{array}{l}213 \\
\left(\mathrm{CO}_{2}\right)+ \\
70 \\
\left(\mathrm{H}_{2} \mathrm{O}\right)\end{array}$ & 86.0 & 8.0 \\
\hline $\begin{array}{l}\text { Gibbs free } \\
\text { energy } \\
\text { change, - } \\
\Delta_{\mathrm{r}} G^{\circ} \mathrm{kJ} \mathrm{mol}^{-} \\
\begin{array}{l}1 \\
1)\end{array}\end{array}$ & 429.0 & 0.0 & 314.0 & 547.0 & 99.5 & 89.2 \\
\hline $\begin{array}{l}\text { Gibbs free } \\
\text { energy } \\
\text { change, - } \\
\Delta_{\mathrm{r}} G^{\circ} \mathrm{kJ} \mathrm{mol}^{-} \\
\begin{array}{l}2 \text { 2) }\end{array}\end{array}$ & 429.0 & -16.4 & 311.0 & 548.0 & 96.5 & 92.4 \\
\hline $\begin{array}{l}\text { Gibbs free } \\
\text { energy } \\
\text { change, - } \\
\Delta_{\mathrm{r}} G^{\prime \mathrm{m}} \mathrm{kJ} \\
\mathrm{mol}^{-1}{ }^{2)}\end{array}$ & 446.0 & 0.7 & 328.0 & 565.0 & 105.0 & 91.9 \\
\hline $\begin{array}{l}\text { Gibbs free } \\
\text { energy } \\
\text { change, - } \\
\Delta_{\mathrm{r}} G^{\prime} \mathrm{kJ} \mathrm{mol}^{-1} \\
\text { 3) }\end{array}$ & 437.6 & 5.0 & 324.7 & 553.5 & 105.9 & 89.2 \\
\hline $\begin{array}{l}\text { Concentratio } \\
\mathrm{n} \text { in medium } \\
(\mathrm{mM})\end{array}$ & 16 & 0.24 & 3.0 & $\begin{array}{l}44(3.7 \\
\mathrm{g} / \mathrm{L} \\
\text { sodium } \\
\text { bicarbo } \\
\text { nate })\end{array}$ & & \\
\hline
\end{tabular}

Arbitrarily selected irrelevant parameters Molecular $180 \quad 32$ $90 \quad 44$ 0.0 0.0

Weight 
bioRxiv preprint doi: https://doi.org/10.1101/2021.11.16.468557; this version posted November 19,2021 . The copyright holder for this preprint (which was not certified by peer review) is the author/funder, who has granted bioRxiv a license to display the preprint in perpetuity. It is made available under aCC-BY-ND 4.0 International license.

665 1) At $298.15 \mathrm{~K}, 1 \mathrm{Bar}, \mathrm{pH} 7$, ionic strength $0.1 \mathrm{M}$ retrieved from (Alberty, 1998).

2) Retrieved from eQuilibrator $\mathrm{pH} 7$, ionic strength $0.1 \mathrm{M}$ on 24th March 2021 (https://equilibrator.weizmann.ac.il/).

3) Calculated from $\Delta_{\mathrm{r}} G^{\prime \mathrm{m}} \mathrm{kJ} \mathrm{mol}^{-1}$ at $310.15 \mathrm{~K}$ given concentration.

4) Retrieved from Calculla (https://calculla.com/standard_entropy).

670 5) Retrieved from Wikipedia (https://ja.wikipedia.org/).

6) Retrieved from PubChem (https://pubchem.ncbi.nlm.nih.gov/). 
Table S5 Standard enthalpy of formation

\begin{tabular}{|c|c|}
\hline & $\Delta_{\mathrm{r}} H^{\circ} \mathrm{kJ} \mathrm{mol}^{-11)}$ \\
\hline Glucose & -1266 \\
\hline $\mathrm{CO}_{2}$ total & -693 \\
\hline $\mathrm{H}_{2} \mathrm{O}$ & -286 \\
\hline Lactate & -688 \\
\hline $\mathrm{NH}_{4}{ }^{+}\left(\mathrm{NH}_{3}(\mathrm{aq})\right)$ & -133 \\
\hline Glutamine & -808 \\
\hline Glutamate & -982 \\
\hline Urea & -319 \\
\hline $\mathrm{O}_{2}$ & -11.7 \\
\hline $\mathrm{H}^{+}$ & 0 \\
\hline Alanine & -557 \\
\hline Proline & $-515^{4)}$ \\
\hline Phosphate & -1300 \\
\hline Arginine & $-621^{4)}$ \\
\hline Isoleucine & $-638^{4)}$ \\
\hline Leucine & $-637^{4)}$ \\
\hline Lysine & $-756^{5)}$ \\
\hline Phenylalanine & $-467^{4)}$ \\
\hline Threonine & $-807^{4)}$ \\
\hline Tryptophan & $-415^{4)}$ \\
\hline Tyrosine & $-685^{4)}$ \\
\hline Valine & $-617^{4)}$ \\
\hline Histidine & $-467^{4)}$ \\
\hline Methionine & $-578^{4)}$ \\
\hline Ornithine & $-694^{2)}$ \\
\hline Aspartate & -945 \\
\hline Asparagine & $-789.4^{4)}$ \\
\hline $\mathrm{Na}+$ & $-240^{4)}$ \\
\hline $\mathrm{Cl}-$ & $-167^{4)}$ \\
\hline Glycine & -525 \\
\hline Serine & $-732.7^{4)}$ \\
\hline Citrate & -1514 \\
\hline Biomass & $-5.5 \mathrm{~kJ} / \mathrm{g}^{3)}$ \\
\hline
\end{tabular}

1) At 298.15 K, 1 Bar, pH 7, ionic strength 0.1M retrieved from (Alberty, 1998).

2) Collected from (Lutkin et al., 2017).

3) Collected from (Popovic, 2019). Means of yeast data were used in this study.

4) Collected from textbook (Atkins et al. Physical Chemistry for the Life Sciences)

5) Collected from (Lytkin et al., 2018). 
Table S6 RNAseq analysis of HCT116 and MCF-7 cells cultured under different temperatures

(A) Summary of RNAseq analysis

\begin{tabular}{lllll}
\hline SampleName & NumOfReads & reference & mapping_rate & NumOfGeneCountZero \\
\hline MCF-7_36 ${ }^{\circ} \mathrm{C}$ & $15,559,985$ & hg19 & $95.20 \%$ & $10,029 / 26,256$ \\
MCF-7_37 ${ }^{\circ} \mathrm{C}$ & $19,105,357$ & hg19 & $95.30 \%$ & $9,681 / 26,256$ \\
MCF-7_38 ${ }^{\circ} \mathrm{C}$ & $18,858,384$ & hg19 & $95.40 \%$ & $9,576 / 26,256$ \\
HCT116_36 $\mathrm{C}$ & $19,749,645$ & hg19 & $94.60 \%$ & $9,769 / 26,256$ \\
HCT116_37 $\mathrm{C}$ & $21,646,230$ & hg19 & $94.80 \%$ & $9,714 / 26,256$ \\
HCT116_38 ${ }^{\circ} \mathrm{C}$ & $18,735,250$ & hg19 & $94.20 \%$ & $9,821 / 26,256$ \\
\hline
\end{tabular}

(B) Comparison of gene expression level

\begin{tabular}{llll}
\hline & HCT166 & MCF-7 & HCT166 \& MCF-7 \\
\hline $\begin{array}{l}36^{\circ} \mathrm{C}<37^{\circ} \mathrm{C} \\
<38^{\circ} \mathrm{C}\end{array}$ & 3606 & 3975 & 619 \\
$36^{\circ} \mathrm{C}>37^{\circ} \mathrm{C}$ & & & \\
$<38^{\circ} \mathrm{C}$ & 4906 & 3793 & 959 \\
$36^{\circ} \mathrm{C}>37^{\circ} \mathrm{C}$ & & & 686 \\
$>38^{\circ} \mathrm{C}$ & 3154 & 4533 & \\
$36^{\circ} \mathrm{C}<37^{\circ} \mathrm{C}$ & 5208 & 4576 & 1144 \\
$>38^{\circ} \mathrm{C}$ & 9382 & 9379 & not determined \\
$\begin{array}{l}\text { Others (ex. Zero } \\
\text { expression) }\end{array}$ & & & \\
\hline
\end{tabular}


Table S7 Gene enrichment analysis using the KEGG 2019 human dataset by Enrichr

\begin{tabular}{|c|c|c|}
\hline Term & $\begin{array}{l}\text { Adjusted P- } \\
\text { value }\end{array}$ & Genes \\
\hline Cell cycle & $1.43 \mathrm{E}-05$ & $\begin{array}{l}\text { PCNA;PLK1;CDC6;CDC25A;CCNA2;PTTG1;CC } \\
\text { NE2;ORC1;TFDP2;ESPL1;ORC3;MDM2;CDK1; } \\
\text { MCM3;ANAPC4;ANAPC5;E2F3;MCM6 }\end{array}$ \\
\hline Proteasome & $1.43 \mathrm{E}-05$ & $\begin{array}{l}\text { PSMA5;PSMA6;PSMD12;PSMD6;PSMA3;PSMA } \\
\text { 2;PSMC1;POMP;PSMB1;PSME4;PSMD1 }\end{array}$ \\
\hline Spliceosome & $2.10 \mathrm{E}-05$ & $\begin{array}{l}\text { TCERG1;HNRNPA3;RBM8A;DDX46;SF3B6;SRS } \\
\text { F1;HNRNPU;WBP11;LSM3;U2SURP;HNRNPK;P } \\
\text { RPF3;TRA2B;SRSF3;SNRPF;SRSF6;SMNDC1;R } \\
\text { BMX }\end{array}$ \\
\hline $\begin{array}{l}\text { DNA } \\
\text { replication }\end{array}$ & $8.40 \mathrm{E}-05$ & $\begin{array}{l}\text { RFC5;PCNA;RNASEH1;RFC4;LIG1;RPA1;MCM } \\
\text { 3;MCM6;DNA2 }\end{array}$ \\
\hline $\begin{array}{l}\text { Citrate cycle } \\
\text { (TCA cycle) }\end{array}$ & $1.54 \mathrm{E}-04$ & $\begin{array}{l}\text { PDHA1;MDH2;IDH3G;IDH2;IDH3B;OGDHL;DL } \\
\text { AT;SDHD }\end{array}$ \\
\hline $\begin{array}{l}\text { Oocyte } \\
\text { meiosis }\end{array}$ & 7.20E-03 & $\begin{array}{l}\text { PLK1;PPP2CA;PPP1CC;RPS6KA3;PPP3CB;PTT } \\
\text { G1;CCNE2;ESPL1;CDK1;ANAPC4;ANAPC5;CA } \\
\text { LM1;CAMK2G }\end{array}$ \\
\hline $\begin{array}{l}\text { Mismatch } \\
\text { repair }\end{array}$ & 2.34E-02 & RFC5;PCNA;RFC4;LIG1;RPA1 \\
\hline $\begin{array}{l}\text { Pyruvate } \\
\text { metabolism }\end{array}$ & 4.13E-02 & $\begin{array}{l}\text { ALDH3A2;LDHA;PDHA1;MDH2;DLAT;ALDH7 } \\
\text { A1 }\end{array}$ \\
\hline
\end{tabular}


Table S8 Metabolic model for ${ }^{13} \mathrm{C}$-MFA

\begin{tabular}{|c|c|c|}
\hline Reaction ID & Stoichiometry & Atom mapping \\
\hline \multirow[t]{2}{*}{ r1_Glc_uptake } & SubsGlc + ATP --> G6P & ABCDEF --> \\
\hline & & $\mathrm{ABCDEF}$ \\
\hline \multirow[t]{2}{*}{ r2_PGI_fw } & G6P --> F6P & ABCDEF --> \\
\hline & & $\mathrm{ABCDEF}$ \\
\hline \multirow[t]{2}{*}{ r3_PGI_rv } & F6P --> G6P & ABCDEF --> \\
\hline & & $\mathrm{ABCDEF}$ \\
\hline \multirow[t]{2}{*}{ r4_PFK } & $\mathrm{F} 6 \mathrm{P}+\mathrm{ATP}-->\mathrm{FBP}$ & ABCDEF --> \\
\hline & & $\mathrm{ABCDEF}$ \\
\hline r5_FBA_fw & FBP --> DHAP + GAP & $\begin{array}{l}\mathrm{ABCDEF}-->\mathrm{CBA}+ \\
\mathrm{DEF}\end{array}$ \\
\hline \multirow[t]{2}{*}{ r6_FBA_rv } & DHAP + GAP --> FBP & $\mathrm{CBA}+\mathrm{DEF}-->$ \\
\hline & & $\mathrm{ABCDEF}$ \\
\hline r7_TPI_fw & DHAP --> GAP & $A B C-->A B C$ \\
\hline r8_TPI_rv & GAP --> DHAP & $\mathrm{ABC}-->\mathrm{ABC}$ \\
\hline r9_GAPDH_fw & GAP --> PGA + NADH + ATP & $\mathrm{ABC}-->\mathrm{ABC}$ \\
\hline r10_GAPDH_rv & $\mathrm{PGA}+\mathrm{NADH}+\mathrm{ATP}-->\mathrm{GAP}$ & $\mathrm{ABC}-->\mathrm{ABC}$ \\
\hline r11_PEPH_fw & PGA --> PEP & $\mathrm{ABC}-->\mathrm{ABC}$ \\
\hline r12_PEPH_rv & PEP --> PGA & $\mathrm{ABC}-->\mathrm{ABC}$ \\
\hline r13_PK & PEP --> Pyr + ATP & $\mathrm{ABC}-->\mathrm{ABC}$ \\
\hline r16_PDH & $\begin{array}{l}\text { Pyr --> AcCOAmit + CO2in }+ \\
\text { NADH }\end{array}$ & $\mathrm{ABC}-->\mathrm{BC}+\mathrm{A}$ \\
\hline \multirow[t]{2}{*}{ r17_CS } & AcCOAmit + Oxa --> Cit & $\mathrm{AB}+\mathrm{CDEF}-->$ \\
\hline & & FEDBAC \\
\hline \multirow[t]{2}{*}{ r18_IDH_fw } & Cit --> aKG + CO2in + NADH & ABCDEF --> \\
\hline & & $\mathrm{ABCDE}+\mathrm{F}$ \\
\hline \multirow[t]{2}{*}{ r19_IDH_rv } & $\mathrm{aKG}+\mathrm{CO} 2 \mathrm{in}+\mathrm{NADH}-->\mathrm{Cit}$ & $\mathrm{ABCDE}+\mathrm{F}-->$ \\
\hline & & ABCDEF \\
\hline r20_AKGDH & $\begin{array}{l}\text { aKG --> Suc + CO2in + ATP + } \\
\text { NADH }\end{array}$ & $\begin{array}{l}\mathrm{ABCDE}-->\mathrm{BCDE}+ \\
\mathrm{A}\end{array}$ \\
\hline r21_SDH_fw & Suc-->Fum $+\{0.6\} N A D H$ & $A B C D ~-->A B C D$ \\
\hline & Fum $+\{0.6\}$ NADH-->Suc & $A B C D ~-->A B C D$ \\
\hline r23_FH_fw & Fum-->Mal & $A B C D-->A B C D$ \\
\hline r24_FH_rv & Mal-->Fum & $A B C D ~-->A B C D$ \\
\hline r25_MDH_fw & Mal --> Oxa+NADH & $A B C D ~-->A B C D$ \\
\hline r26_MDH_rv & Oxa+NADH --> Mal & $A B C D ~-->A B C D$ \\
\hline r27_PC & $\mathrm{Pyr}+\mathrm{CO} 2 \mathrm{in}+\mathrm{ATP}-->\mathrm{Oxa}$ & $\mathrm{ABC}+\mathrm{D}-->\mathrm{ABCD}$ \\
\hline r28_MAE & Mal --> Pyr + CO2in + NADPH & $\mathrm{ABCD}-->\mathrm{ABC}+\mathrm{D}$ \\
\hline \multirow[t]{2}{*}{ r29_G6PDH } & G6P --> m6PG + NADPH & ABCDEF --> \\
\hline & & $\mathrm{ABCDEF}$ \\
\hline \multirow[t]{2}{*}{ r30_6PGDH } & m6PG --> Ru5P + CO2in + NADPH & ABCDEF --> \\
\hline & & $\mathrm{BCDEF}+\mathrm{A}$ \\
\hline r31_RPI_fw & Ru5P --> R5P & ABCDE --> ABCDE \\
\hline r32_RPI_rv & R5P --> Ru5P & ABCDE --> ABCDE \\
\hline r33_RPE_fw & Ru5P --> Xu5P & ABCDE --> ABCDE \\
\hline r34_RPE_rv & Xu5P --> Ru5P & ABCDE --> ABCDE \\
\hline
\end{tabular}




\begin{tabular}{|c|}
\hline 5_TKL1_fw \\
\hline r36_TKL1_rv \\
\hline r37_TAL1_fw \\
\hline r38_TAL1_rv \\
\hline r39_TKL2_fw \\
\hline r40_TKL2_rv \\
\hline $\begin{array}{l}\text { r41_LDH } \\
\text { r42_Lac_excretion } \\
\text { r46_Gln_uptake } \\
\text { r47_GLC } \\
\text { r49_GDH_fw } \\
\text { r50_GDH_rv } \\
\text { r51_Glu_excretion } \\
\text { r52_Pro } \\
\text { r53_Pro_excretion } \\
\text { r54_Asp } \\
\text { r55_Asp_excretion } \\
\text { r56_Asn } \\
\text { r57_Asn_excretion } \\
\text { r58_GPT } \\
\text { r59_Ala_excretion } \\
\text { r71_Leu_uptake }\end{array}$ \\
\hline r72_Ile_uptake \\
\hline $\begin{array}{l}\text { r75_Val_uptake } \\
\text { r77_Arg_uptake }\end{array}$ \\
\hline r78_Arg_degradatic \\
\hline $\begin{array}{l}\text { r79_Orn_excretion } \\
\text { r82_ACYL }\end{array}$ \\
\hline $\begin{array}{l}\text { r83_AcCOA_BIO } \\
\text { r84_G6P_BIO } \\
\text { r85_R5P_BIO } \\
\text { r86_DHAP_BIO } \\
\text { r87_Ser_BIO } \\
\text { r89_Ala_BIO } \\
\text { r90_Asp_BIO } \\
\text { r91_Asn_BIO } \\
\text { r92_Glu_BIO }\end{array}$ \\
\hline
\end{tabular}

$$
\begin{aligned}
& \text { R5P + Xu5P --> S7P + GAP } \\
& \text { GAP + S7P --> Xu5P + R5P } \\
& \text { GAP + S7P --> F6P + E4P } \\
& \text { E4P + F6P --> S7P + GAP } \\
& \text { E4P + Xu5P --> F6P + GAP } \\
& \text { GAP + F6P --> Xu5P + E4P } \\
& \text { Pyr + NADH --> Lac } \\
& \text { Lac --> LacEx } \\
& \text { SubsGln --> Gln } \\
& \text { Gln --> Glu } \\
& \text { Glu --> aKG } \\
& \text { aKG --> Glu } \\
& \text { Glu --> GluEx } \\
& \text { Glu --> Pro } \\
& \text { Pro --> ProEx } \\
& \text { Oxacyt --> Asp } \\
& \text { Asp --> AspEx } \\
& \text { Asp --> Asn } \\
& \text { Asn --> AsnEx } \\
& \text { Pyr --> Ala } \\
& \text { Ala --> AlaEx } \\
& \text { SubsLeu --> Leu } \\
& \text { SubsIle --> Ile } \\
& \text { SubsVal --> Val } \\
& \text { SubsArg --> Arg } \\
& \text { Arg --> Glu --> OrnEx } \\
& \text { Cit --> AcCOAcyt + Oxacyt }
\end{aligned}
$$

AcCOAcyt --> AcCOABiomass

G6P --> G6PBiomass

R5P --> R5PBiomass

DHAP --> DHAPBiomass

PGA --> SerBiomass

Ala --> AlaBiomass

Asp --> AspBiomass

Asn --> AsnBiomass

Glu --> GluBiomass

ABCDE + FGHIJ -->
FGABCDE + HIJ
HIJ + FGABCDE -->
FGHIJ + ABCDE
ABC + DEFGHIJ -->
DEFABC + GHIJ
GHIJ + DEFABC -->
DEFGHIJ + ABC
ABCD + EFGHI -->
EFABCD + GHI
GHI + EFABCD -->
EFGHI + ABCD
ABC --> ABC
nd
ABCDE --> ABCDE
ABCDE --> ABCDE
ABCDE --> ABCDE
ABCDE --> ABCDE
nd
ABCDE --> ABCDE
nd
ABCD --> ABCD
nd
ABCD --> ABCD
nd
ABC --> ABC
nd
ABCDEF -->
ABCDEF
ABCDEF -->
ABCDEF
ABCDE --> ABCDE
ABCDEF -->
ABCDEF
ABCDEF -->
ABCDE
nd
FEDBAC --> AB +
nd
nd
nd
nd
nd




\begin{tabular}{lll} 
r93_Gln_BIO & Gln --> GlnBiomass & nd \\
r94_Pro_BIO & Pro --> ProBiomass & nd \\
r95_Arg_BIO & Arg --> ArgBiomass & nd \\
r96_Leu_BIO & Leu --> LeuBiomass & nd \\
r97_Ile_BIO & Ile --> IleBiomass & nd \\
r98_Val_BIO & Val --> ValBiomass & nd \\
r100_CO2_in & CO2in --> CO2Ex & A --> A \\
r101_CO2_ex & SubsCO2 --> CO2in & A --> A \\
r104_MAL_transport_fw & Mal --> Malcyt & ABCD --> ABCD \\
r105_MAL_transport_rv & Malcyt --> Mal & ABCD --> ABCD \\
r106_MDH_cyt_fw & Malcyt --> Oxacyt + NADH & ABCD --> ABCD \\
r107_MDH_cyt & Oxacyt + NADH --> Malcyt & ABCD --> ABCD \\
r108_Net_ATP_production & ATP --> ATPex & nd \\
r109_OXPHOS & NADH --> 2.5 ATP & nd \\
r110_Net_NADPH_production & NADPH --> NADPHex & nd \\
\hline
\end{tabular}

